OPEN ACCESS

Edited by:

Michael Arthur St. John, Technical University of Denmark,

Denmark

Reviewed by:

Andrew Brierley,

University of St Andrews,

United Kingdom

Patrick Lehodey

Collecte Localisation Satellites, France

${ }^{*}$ Correspondence:

Ryan A. Saunders

ryaund@bas.ac.uk

Specialty section:

This article was submitted to

Marine Ecosystem Ecology,

a section of the journal

Frontiers in Marine Science

Received: 06 February 2019

Accepted: 13 August 2019

Published: 04 September 2019

Citation:

Saunders RA, Hill SL, Tarling GA and Murphy EJ (2019) Myctophid Fish

(Family Myctophidae) Are Central Consumers in the Food Web of the

Scotia Sea (Southern Ocean).

Front. Mar. Sci. 6:530.

doi: 10.3389/fmars.2019.00530

\section{Myctophid Fish (Family Myctophidae) Are Central Consumers in the Food Web of the Scotia Sea (Southern Ocean)}

\author{
Ryan A. Saunders*, Simeon L. Hill, Geraint A. Tarling and Eugene J. Murphy \\ British Antarctic Survey, Natural Environment Research Council, Cambridge, United Kingdom
}

Myctophids are the most abundant and diverse mesopelagic fishes in the Southern Ocean. They are a conduit of energy between primary consumers and higher marine predators, and between the surface layers and the mesopelagic depths. However, there remain major uncertainties about their ecology, particularly regarding their role in Southern Ocean food webs in waters south of the Antarctic Polar Front, which are often regarded as dominated by Antarctic krill. Limited data on the feeding ecology of myctophids has made it difficult to assess the importance of myctophids as consumers of krill and how they fit in the traditional view of a krill-dominated system (diatom-krillhigher predator). We provide a new assessment of the role of myctophids in Southern Ocean food webs using information from recent trophodynamic studies of myctophids conducted in the Scotia Sea, one of the most productive regions of the Southern Ocean and a region that sustains both major populations of higher predators (sea birds, seals, whales) and important commercial fisheries (krill, toothfish, and mackerel icefish). Collectively, these data show that myctophids have a central role in Southern Ocean food webs as both predators and prey. Large myctophid species are prevalent consumers of krill throughout their distributional range and in different seasons in the Scotia Sea. Moreover, best estimates of both myctophid and higher predator consumption of krill to date indicate that large myctophids are the greatest predators of krill in this region, consuming almost as much krill as do all other vertebrates. Nevertheless, there are several smaller myctophid species that do not eat krill, instead consuming copepods and other small euphausiids. Myctophids therefore link primary producers to higher predators through both krill-dependent and krill-independent trophic pathways, emphasizing their importance in regional food webs. Consequently, trophic pathways involving large myctophids are unlikely to be exempt from the direct consequences of projected redistribution and/or reduction in krill population biomass under scenarios of ocean-warming, whilst trophic pathways involving small myctophids may be more resilient to such effects and become increasingly important to higher trophic levels. Further studies are required to determine the extent to which myctophids can maintain food web stability and sustain higher predator populations 
during periods of prolonged reductions in krill abundance. Including knowledge of the role of myctophids in Southern Ocean food webs will be important for developing robust projections of the impacts of future change to inform decision making for conservation and management.

\section{Keywords: Myctophidae, food web, feeding ecology, Scotia Sea, Southern Ocean}

\section{INTRODUCTION}

Myctophids (Family Myctophidae) are the most abundant and diverse mesopelagic fishes in most of the world's oceans (Gjøsaeter and Kawaguchi, 1980), including the Southern Ocean, where they comprise around 35 species in 12 genera and an estimated biomass that may substantially exceed 70-200 million tonnes (Mt) (Hulley, 1981; Lubimova et al., 1987; Irigoien et al., 2014). They are important in the transfer of energy through Southern Ocean food webs, linking primary consumers, and omnivorous macro-zooplankton to a range of higher marine predators, and they also contribute to the export of carbon from the sea surface to mesopelagic depths through their extensive vertical migrations (Smith, 2011). However, there remain major uncertainties in the ecology of myctophids in this ocean, particularly regarding their role in pelagic food webs.

The traditional view of Southern Ocean food webs south of the Antarctic Polar Front (APF) is that of a simple trophic system dominated by Antarctic krill (Euphausia superba, hereafter krill) that links diatom-based primary productivity with higher trophic levels in short, efficient, food chains, sustaining an array of major higher predator populations (Everson, 1977; Laws, 1984; Murphy et al., 2012). However, alternative food web structures dominate in some parts of the Southern Ocean, where other mid-trophic level organisms, such as small euphausiids and mesopelagic fish, may be regionally important in providing the linkage between primary producers and higher trophic levels (Ducklow et al., 2007; Smith et al., 2007; Murphy et al., 2013). Southern Ocean food web structure varies seasonally in response to local variations in physical (currents and sea ice) and chemical (nutrient supply) processes that alter primary production, phytoplankton composition, zooplankton dynamics and predator foraging behavior (Murphy et al., 2007a; Atkinson et al., 2008; Ballerini et al., 2014; Saba et al., 2014). Consequently, alternative trophic pathways operate, although these more complex pathways are not as energy efficient as the krill-based system and cannot support the same level of predator demand (Murphy et al., 2007b, 2012, 2013). A major reassessment of the structure and functioning of Southern Ocean food webs has highlighted the importance of alternative pathways of energy flow (Murphy et al., 2007b, 2012, 2013). Since myctophids are relatively abundant and thought to eat mostly primary consumers, such as copepods and amphipods (Pakhomov et al., 1996; Shreeve et al., 2009), as well as being a major food source for many higher marine predators, including penguins, seals, petrels, squid, and large predatory fish (Olsson and North, 1997; Cherel et al., 2002; Dickson et al., 2004; Reid et al., 2006; Collins et al., 2007; Connan et al., 2007), they have been identified as a major alternative trophic pathway in the Southern Ocean food web
(Murphy et al., 2007b). This concept has been strengthened by evidence that myctophids are important in sustaining abundant higher predator populations temporarily in regions and periods of low krill abundance (Croxall et al., 1999; Murphy et al., 2007b). However, the wider trophic role of myctophids remains poorly understood and there is a need to gain robust myctophid trophodynamics data to improve understanding of their role in Southern Ocean food webs (Murphy et al., 2007b, 2012, 2013) and how this relates to the traditional view of a krill-based food web (Laws, 1984; Pakhomov et al., 1996; Everson et al., 1999).

The significance of krill in myctophid diets has been a source of debate (Rowedder, 1979a; Williams, 1985; Lancraft et al., 1989; Pakhomov et al., 1996; Pusch et al., 2004; Shreeve et al., 2009). Despite major uncertainties regarding their trophodynamics and abundance, recent studies have highlighted that large myctophids could potentially be major predators of krill (Hill et al., 2007; Kock et al., 2012). Uncertainties in the trophodynamics of myctophids exist primarily due to the inherent difficulties in sampling them appropriately, which has restricted studies to the most abundant species on limited spatial and temporal scales, often with very small sample sizes (Rowedder, 1979a; Pakhomov et al., 1996; Gaskett et al., 2001; Pusch et al., 2004; Shreeve et al., 2009). More recently, Saunders et al. (2018) and Saunders et al. (2015a) reported on the trophodynamics of myctophids at larger temporal and spatial scales in the Scotia Sea, providing information more conducive to determining the role that krill play in the feeding ecology of myctophids, and their wider role in regional food webs (Murphy et al., 2007b, 2012, 2013). The need to understand the function of myctophids in the operation of the Southern Ocean food web has been brought sharply into focus by the rapid environmental change in the region and the need to understand the impact this change will have on the structure and resilience of the local marine ecosystem (Atkinson et al., 2004, 2019; Whitehouse et al., 2008; Flores et al., 2012; Murphy et al., 2013). With the realistic possibility of reductions in krill stocks in the coming decades, or a southward retreat in its distribution pattern, the importance of alternative trophic pathways in maintaining ecosystem stability is likely to increase in the region (Murphy et al., 2007a). A more detailed assessment of the trophic role of myctophids is therefore necessary to underpin effective management of the impacts of human activities, particularly fishing, throughout the Southern Ocean (Murphy et al., 2012, 2013).

In this study, we assess the role of myctophid fish as consumers in Southern Ocean food webs using published information from contemporary trophodynamic studies in the Scotia Sea (Atlantic sector; Figure 1). We concentrate on the area between $\sim 48^{\circ}$ to $62^{\circ} \mathrm{S}$ and $30^{\circ}$ to $50^{\circ} \mathrm{W}$ (Northern and Southern Scotia Sea; Figure 1), where most of these data were obtained, but consider 


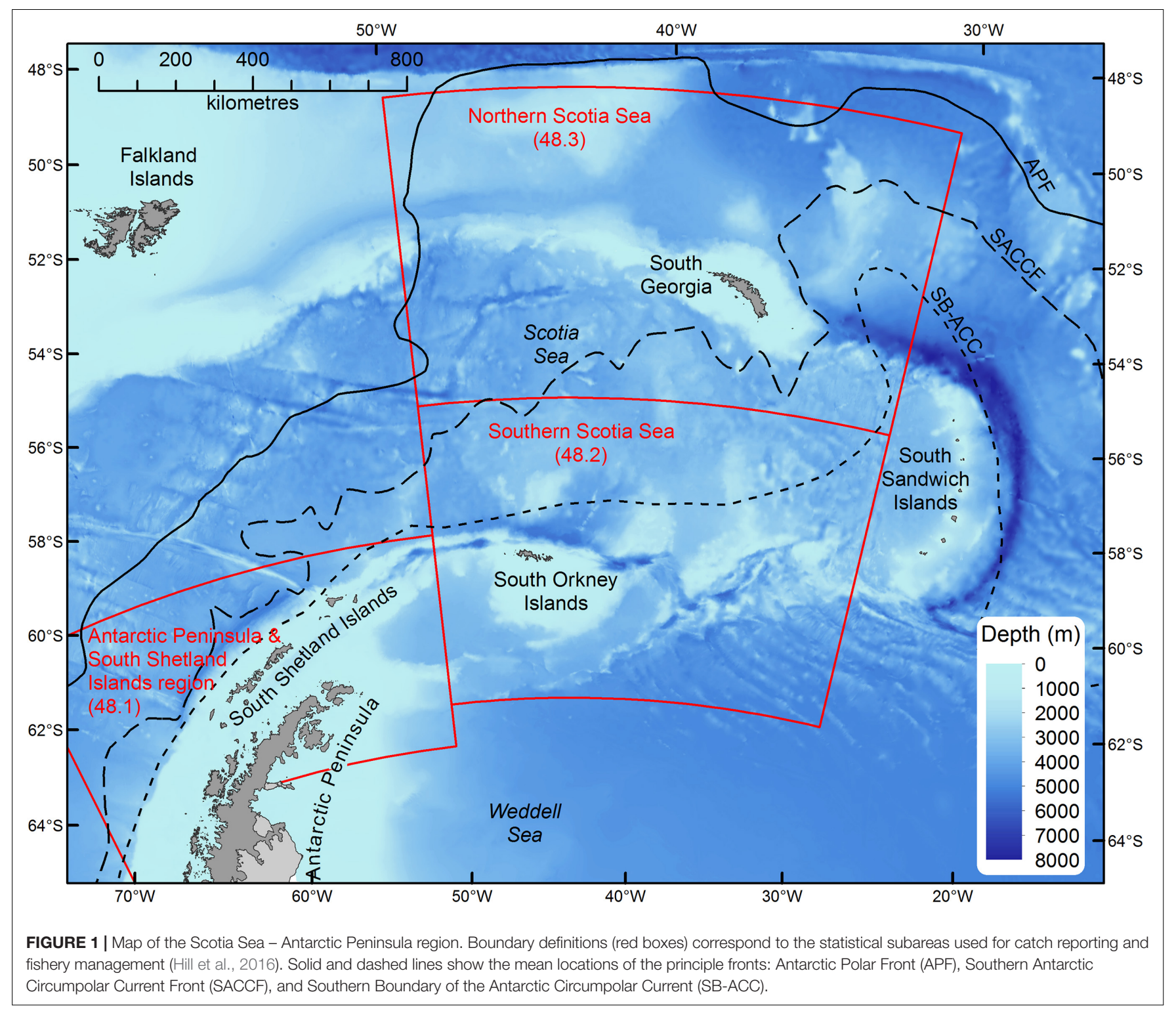

the wider biological and oceanographic links to the adjoining area around the Antarctic Peninsula and South Shetland Islands (Hofmann et al., 1998; Murphy et al., 2007b). In this way, our inferences extend to the broader Scotia Sea - Antarctic Peninsula region (Figure 1). This region provides an interesting case study, as it is one of the most productive regions of the Southern Ocean (Holm-Hansen et al., 2004), estimated to support around half of the circumpolar krill population, which in turn supports major populations of higher predators, such as penguins, whales and seals (Atkinson et al., 2004). The region is important because the Antarctic krill fishery operates almost exclusively in this part of the Southern Ocean (Everson et al., 2000; Hill et al., 2016) and it also supports other important fisheries for Patagonian toothfish (Dissostichus eleginoides) and mackerel icefish (Champsocephalus gunnari) (Everson, 1977; Constable et al., 2000). Historically, the region is where the majority of harvesting of seals, whales and fishes in the Southern
Ocean occurred (Everson, 1977). Furthermore, it is an area where ecological change associated with rapid regional warming is particularly marked (de la Mare, 1997; Curran et al., 2003; Atkinson et al., 2004, 2019; Murphy et al., 2007a; Whitehouse et al., 2008), which may be a useful model system with which to identify the changes in food web dynamics manifested by climate change to compare with elsewhere.

\section{ECOLOGICAL FEATURES OF SCOTIA SEA MYCTOPHIDS}

\section{Community Composition and Distribution}

Although generally krill-dominated, the Scotia Sea has a substantial, depth-stratified myctophid community that includes 
around 15 species in 5 genera, comprising an estimated biomass of around 4.5 Mt based on netting surveys conducted between 2006 and 2009 (Hulley, 1981; Collins et al., 2012). Other rare species occur occasionally in this region, but they are only minor in terms of both abundance and biomass (Hulley, 1981, 1990). The Scotia-Weddell Front generally marks the southernmost limit to the distribution of the Scotia Sea myctophid community (Lancraft et al., 1989). North of this front, myctophids occur mostly between the mixed layer depth $(\sim 50-100 \mathrm{~m})$ and $1000 \mathrm{~m}$ throughout the year, with the greatest concentrations found generally around frontal waters, such as the APF and South Antarctic Circumpolar Current Front (SACCF), and the shelf-break waters of the Antarctic and sub-Antarctic Islands (Lancraft et al., 1989; Pusch et al., 2004; Collins et al., 2008; Donnelly and Torres, 2008; Saunders et al., 2015c; Lourenço et al., 2017). However, interspecific patterns in distribution and abundance are apparent for the biomass-dominant species in the region, which vary seasonally, ontogenetically and with temperature and latitude for most species (Collins et al., 2012; Saunders et al., 2015b; Saunders and Tarling, 2018). In general, Electrona antarctica and Gymnoscopelus braueri are the most abundant species south of the APF (Table 1). These species occur throughout the Scotia Sea, including the cold waters of the sea ice zone in the southern Scotia Sea, where E. antarctica is most abundant (Rowedder, 1979b; Pusch et al., 2004; Saunders et al., 2014). Gymnoscopelus nicholsi and Gymnoscopelus opisthopterus have a similar distribution pattern, but they usually occur only in small numbers (Saunders et al., 2015b). Diversity increases in the warmer waters of the northern Scotia Sea where Krefftichthys anderssoni, Electrona carlsbergi, and Protomyctophum bolini are often the most abundant species in the community (Piatkowski et al., 1994; Collins et al., 2008; Saunders et al., 2015c; Lourenço et al., 2017). Protomyctophum tenisoni, Gymnoscopelus fraseri, Nannobrachium achirus, and Protomyctophum choriodon seldom occur in waters south of the SACCF and are predominantly found in the northern Scotia Sea, especially in waters associated with either the APF, or the Georgia Basin (Collins et al., 2008; Saunders et al., 2015b,c).

\section{Vertical Distribution and Behavior}

Although there is some evidence of seasonal variations in the depth distribution of myctophids in the Scotia Sea (Pusch et al., 2004; Collins et al., 2008; Saunders et al., 2015c; Lourenço et al., 2017), most species occur predominantly in the upper $400 \mathrm{~m}$ of the water column, or have populations that span these waters throughout the year (Table 1). The main exceptions are G. opisthopterus, N. achirus, and K. anderssoni, which are mostly distributed below $400 \mathrm{~m}$ in the deep-water masses. Most Southern Ocean myctophids are thought to undertake diel vertical migrations to the surface layers to feed at night, with the vertical extent of such behavior typically exceeding $200 \mathrm{~m}$ and individuals clearly crossing thermoclines and haloclines that demark the transition between epipelagic $(<200 \mathrm{~m})$ and deeper water masses (Zasel'sliy et al., 1985; Lancraft et al., 1989; Perissinotto and McQuaid, 1992; Piatkowski et al., 1994; Duhamel et al., 2000; Koubbi et al., 2001; Robison, 2003; Pusch et al., 2004; Collins et al., 2008; Flynn and Williams, 2012; Saunders et al., 2014, 2015b,c; Moteki et al., 2017). Therefore, apart from the deep-dwelling species, the overall patterns in myctophid depth distribution broadly overlap with those of their main zooplankton prey and the vertical foraging range of their air breathing predators throughout the year (Reid et al., 2006; Scheffer et al., 2012; Saunders et al., 2018). However, myctophid vertical migration behavior appears to be complex and understanding is confounded by daytime net avoidance throughout the Southern Ocean such that species-specific patterns are yet to be fully resolved. Other myctophid behavioral mechanisms that are important from a food web dynamics perspective include schooling, and many Southern Ocean myctophid species are generally thought to move through the ocean in dense aggregations that vary in size up to $\sim 42,000 \mathrm{~m}^{2}$ (Zasel'sliy et al., 1985;

TABLE 1 | Summary of the predominant species of the Scotia Sea myctophid community (Hulley, 1981; Linkowski, 1985; Lubimova et al., 1987; Greely et al., 1999; Collins et al., 2008; Saunders et al., 2014, 2015b,c; Lourenço et al., 2017).

\begin{tabular}{|c|c|c|c|c|c|c|c|}
\hline Species & Type/Pattern & $\begin{array}{c}\text { Approx. } \\
\text { distributional } \\
\text { range (adults) }\end{array}$ & $\begin{array}{l}\text { Approx. depth } \\
\text { distribution } \\
\text { (m) }\end{array}$ & $\begin{array}{l}\text { Approx. } \\
\text { max. size } \\
\text { (SL, mm) }\end{array}$ & $\begin{array}{c}\text { Est. lifespan } \\
\text { (year) }\end{array}$ & $\begin{array}{c}\text { Median } \\
\text { abundance } \\
\text { (ind. } \mathbf{m}^{-2} \text { ) }\end{array}$ & $\begin{array}{c}\text { Abundance } \\
\text { percentiles } \\
\text { (ind. } \mathrm{m}^{-2} \text { ) }\end{array}$ \\
\hline Electrona carlsbergi & South temperate & STF to APF & $0-400$ & 93 & 5 & 0.015 & $0.002-0.207$ \\
\hline Electrona antarctica & Antarctic & APF to SIZ & $0-1000$ & 115 & 4 & 0.155 & $0.003-0.586$ \\
\hline Gymnoscopelus fraseri & South temperate & STF to APF & $0-400$ & 115 & 3 & 0.007 & $0.002-0.048$ \\
\hline Gymnoscopelus nicholsi & Broadly Antarctic & STF to SIZ & $0-1000$ & 165 & 7 & 0.004 & $0.002-0.015$ \\
\hline Gymnoscopelus braueri & Broadly Antarctic & STF to SIZ & $0-1000$ & 162 & 4 & 0.078 & $0.002-0.431$ \\
\hline Gymnoscopelus opisthopterus & Antarctic & STF to SIZ & $400-1000$ & 187 & 5 & 0.003 & $0.002-0.030$ \\
\hline Krefftichthys anderssoni & Broadly Antarctic & STF to SACCF & $200-1000$ & 75 & 3 & 0.067 & $0.002-0.346$ \\
\hline Nannobrachium achirus & South temperate & STF to APF & $200-1000$ & 167 & 4 & 0.006 & $0.003-0.033$ \\
\hline Protomyctophum bolini & Broadly Antarctic & STF to SACCF & $200-700$ & 78 & 2 & 0.032 & $0.002-0.143$ \\
\hline Protomyctophum choriodon & South Temperate & STF to SACCF & $0-400$ & 85 & 4 & 0.003 & $0.002-0.030$ \\
\hline Protomyctophum tenisoni & Broadly Antarctic & STF to APF & $0-700$ & 58 & 2 & 0.006 & $0.002-0.084$ \\
\hline
\end{tabular}

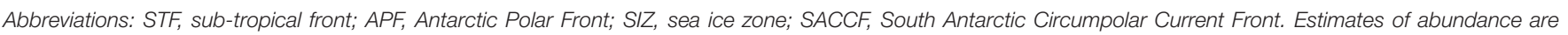
depth-integrated net catch (RMT25) concentrations collected between 0 and $1000 \mathrm{~m}$ in different seasons, with the 25th and 75th percentiles (Saunders et al., 2015a). 
Perissinotto and McQuaid, 1992; Reid et al., 2006; Collins et al., 2008; Fielding et al., 2012; Saunders et al., 2013). These large aggregations may also vary spatially in response to local predatory threats over short spatial/temporal scales and differences in oceanographic conditions, such as current velocity (Saunders et al., 2013). However, there is still a need for more information on the schooling behavior of all species in the Southern Ocean.

\section{Life Cycle Characteristics}

Myctophids in the Scotia Sea attain body sizes between $\sim 55$ and $170 \mathrm{~mm}$ (standard length; SL) and have life cycles lasting between 2 and 7 years (Greely et al., 1999) (Table 1). All species in this region have a relatively high energy content and are suitable as prey for most higher predators in terms of their size spectra and their availability in the region across multiple years and seasons (Ruck et al., 2014). Myctophids that attain a size sufficient to consume large $(>40 \mathrm{~mm})$ macrozooplankton, such as krill and large amphipods, include $N$. achirus, and the Electrona and Gymnoscopelus species. Most species are thought to reach sexual maturity after $\sim 1.5-3$ years and are generally assumed to have low fecundity (Hulley, 1981; Oven et al., 1990). However, the majority of the biomass-dominant species are migrants in the Scotia Sea where they form non-reproducing sink populations (Hulley, 1981; Efremenko, 1986; Saunders et al., 2017). With the exception of E. antarctica and K. anderssoni (Efremenko, 1986; Belchier and Lawson, 2013), Scotia Sea myctophids appear to have predominantly temperate or sub-tropical origins, with the full reproductive populations recruiting north of the APF and only expatriate populations of increased body size occurring at latitudes farther south (Hulley, 1981; Leob et al., 1993; Saunders et al., 2017). The southernmost extent to which myctophids can penetrate the colder high latitude waters appears to be governed by the maximum body size that they can attain, with only the largest sized species, such as E. antarctica, G. braueri, and
G. nicholsi, able to penetrate and inhabit the southernmost waters of the Scotia Sea (Saunders and Tarling, 2018). Oceanographic mechanisms and connections between Antarctic waters and those at lower latitudes, as well as behavioral processes, are therefore clearly important in maintaining the high levels of myctophid biomass in the Scotia Sea and determining their role in this food web.

\section{DIET PATTERNS OF THE MYCTOPHID SPECIES IN THE SCOTIA SEA}

The general diets of several myctophid species have been described in various regions of the Southern Ocean based on conventional stomach contents analyses (Kozlov and Tarverdiyeva, 1989; Pakhomov et al., 1996; Gaskett et al., 2001; Flores et al., 2008), although quantitative data are predominantly limited to the Scotia Sea (Rowedder, 1979a; Oven et al., 1990; Pusch et al., 2004; Shreeve et al., 2009; Saunders et al., 2014, 2015b,c; Lourenço et al., 2017). Consistent with findings from more time-integrated biochemical dietary techniques (Cherel et al., 2010; Stowasser et al., 2012), the available data indicate that Scotia Sea myctophids have broad diets, consuming abundant zooplankton prey above a minimum size ( $\sim 2 \mathrm{~mm}$ ), with their diets being largely dominated by planktic crustaceans, particularly large copepods, small euphausiids, and amphipods (Shreeve et al., 2009). However, soft-bodied organisms, such as salps, chaetognaths, pteropods, and jellies, are most likely underrepresented in such analysis methods and their true prevalence in myctophid diets remains largely unknown. Myctophid size is an important determinant of diet within the Scotia Sea community, with larger-sized fish clearly predating a broader range of prey taxa and consuming both larger prey species and larger body sizes within species (Rowedder, 1979a; Shreeve et al., 2009; Saunders et al., 2015a, 2018) (Figure 2).

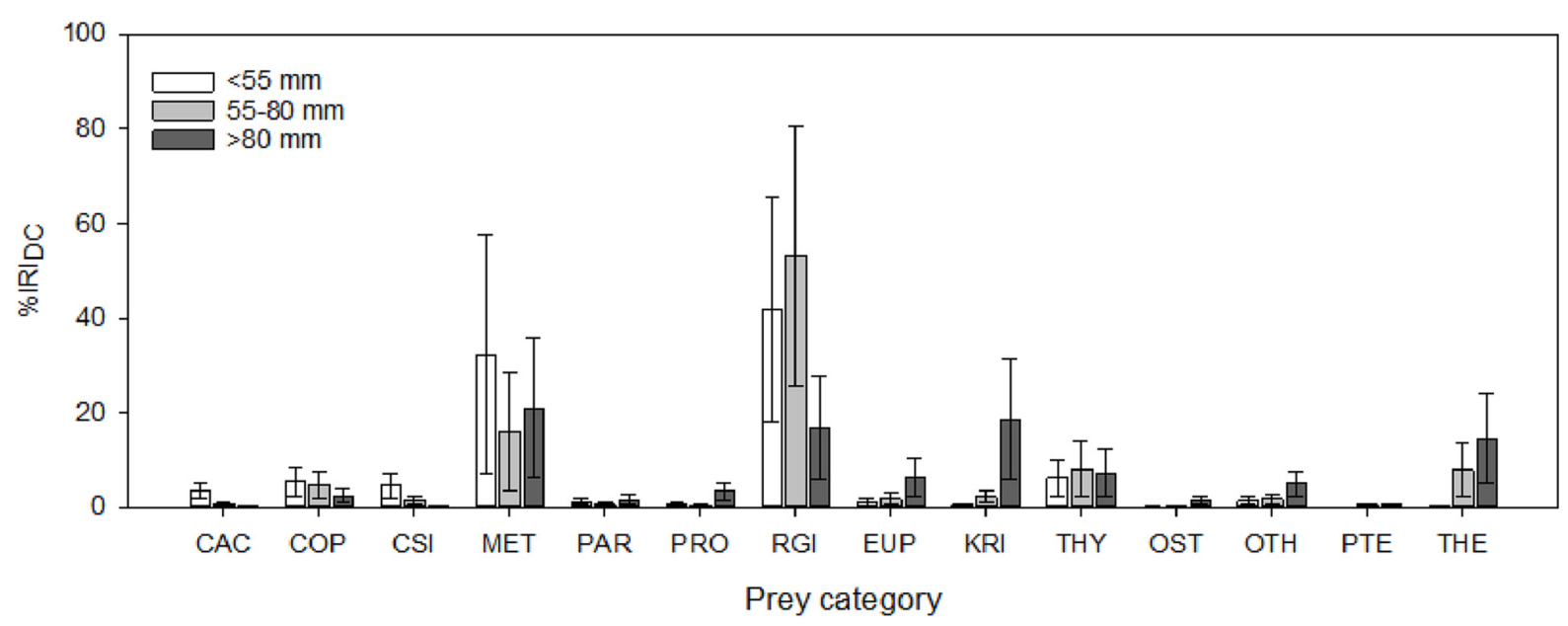

FIGURE 2 | Variation in the diet composition of the Scotia Sea community with body size (SL, mm), expressed as the percentage index of relative importance $\left(\% \mid R I_{D C}\right)$. Error bars are bootstrapped 95\% confidence intervals. CAC, Calanoides acutus; COP, other copepods; CSI, Calanus simillimus; MET, Metridia spp.; PAR, Paraeuchaeta spp.; PRO, Pleuromamma robusta; RGI, Rhincalanus gigas; EUP, other euphausiids; KRI, Euphausia superba; THY, Thysanoessa spp.; OST, ostracods; OTH, other taxa (predominantly unidentified crustaceans); PTE, pteropods; THE, Themisto gaudichaudii. 
An increase in trophic level with increasing myctophid size was also detected in the region using stable isotope analyses (Tarling et al., 2012).

Evidence that the Scotia Sea myctophid community exhibits a high degree of prey selectivity was presented by Shreeve et al. (2009), who showed that myctophids preferentially predate the larger, more lipid-rich, copepodite stages within the copepod component of the prey field. Furthermore, Saunders et al. (2015a) indicated that myctophids select certain species of euphausiid over others that are comparable in size, energy composition, abundance and vertical distribution patterns, suggesting that differences in prey aggregation and escape behavior are also important in myctophid prey selection. Myctophids have a relatively high overlap in their overall diets in the Scotia Sea, with many prey species contributing significantly to diets of all myctophids (Tables 2-5). However, there is some evidence of dietary niche segregation and specialization for some myctophid species, such as E. antarctica, which is linked partly to horizontal and vertical distribution and individual size, with feeding guilds that may change seasonally (Shreeve et al., 2009; Stowasser et al., 2012; Saunders et al., 2015a, 2018). Such resource partitioning, together with high regional food availability throughout the Scotia Sea (Ward et al., 2012), is likely to be important in minimizing inter-specific competition in the region (Schoener, 1974). The overall diet compositions of the biomass-dominant myctophid species in the Scotia Sea are summarized below.

\section{Electrona Diet Composition}

Based on data collected from surveys across the entire latitudinal range of Scotia Sea in spring, summer, and autumn, the overall diet of E. antarctica (115 mm maximum standard length; hereafter $\mathrm{SL}_{\max }$ ) is apparently dominated by krill (Euphausia superba) and the amphipod Themisto gaudichaudii (Saunders et al., 2014) (Table 2). Krill comprise over 50\% of its diet by mass (percentage mass; $\% \mathrm{M}$ ), which is consistent with findings from studies conducted around the South Shetland Islands (Pusch et al., 2004), South Georgia, Elephant Island and the South Sandwich Islands (Rowedder, 1979a) during summer. However, krill is a smaller dietary component $(5 \% \mathrm{M})$ of E. antarctica at South Georgia in autumn, where T. gaudichaudii is the dominant prey species (81\%M) (Shreeve et al., 2009). Analyses of diet by size showed that krill in the Scotia Sea are consumed by all E. antarctica size classes $>40 \mathrm{~mm}$, with the greatest proportions taken by individuals $>80 \mathrm{~mm}$, whilst T. gaudichaudii is consumed by specimens $>55 \mathrm{~mm}$ (Saunders et al., 2018).

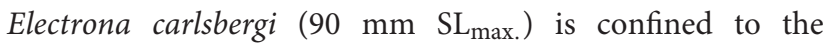
northern Scotia Sea between spring and autumn, with all sizes consuming mostly copepods, particularly Rhincalanus gigas (50\%M) and Paraeuchaeta spp. (4\% M; Table 2) (Saunders et al., 2014). The species consumes the euphausiids Thysanoessa spp. $(6 \% \mathrm{M})$ and krill $(5 \% \mathrm{M})$, although only a minor fraction $(2 \%)$ of the population take krill overall. The amphipod T. gaudichaudii $(8 \% \mathrm{M})$ and pteropods $(6 \% \mathrm{M})$ are also important components of the species' diet. These findings are consistent with those obtained at South Georgia in autumn, although a substantial part of the diet $(27 \% \mathrm{M})$ could only be classified as unidentified crustaceans (Shreeve et al., 2009).

\section{Gymnoscopelus Diet Composition}

The diet of $G$. braueri (162 $\mathrm{mm} \mathrm{SL}_{\text {max. }}$ ) across the Scotia Sea is comprised mostly of euphausiids, amphipods and copepods between spring and autumn (Table 3) (Saunders et al., 2015b). The species consumes substantial proportions of krill (20\%M), Thysanoessa spp. (15\%M) and T. gaudichaudii (16\%M), as well as the copepod $R$. gigas $(5 \% \mathrm{M})$. However, krill are only present in specimens $>80 \mathrm{~mm}$ (Saunders et al., 2018). Both T. gaudichaudii $(44 \% \mathrm{M})$ and krill $(37 \% \mathrm{M})$ are dominant in its diet at South Georgia in autumn and the mysiid Antarctomysis spp. $(7 \% \mathrm{M})$ is also present (Shreeve et al., 2009). Around the South Shetland Islands, euphausiids are dominant in the summer diet of G. braueri, with Euphausia triacantha comprising 24\%M and unidentified Euphausia spp. comprising 65\%M. Amphipods, not identified to species, were also important (10\%M) (Pusch et al., 2004).

Gymnoscopelus fraseri (115 $\mathrm{mm} \mathrm{SL}_{\text {max. }}$ ) is predominantly confined to the northern Scotia Sea in all seasons where its diet is dominated by the copepods Metridia spp. (19\%M), R. gigas $(11 \% \mathrm{M})$, and Pleuromamma robusta $(5 \% \mathrm{M})$ (Saunders et al., 2015b). Euphausiids of the Thysanoessa genus are also a major component of its overall diet $(39 \% \mathrm{M})$, whilst krill is notably absent. $G$. fraseri also consumes substantial proportions of T. gaudichaudii $(16 \% \mathrm{M})$, although this prey is only found in specimens $>80 \mathrm{~mm}$ (Saunders et al., 2018). The species diet is broadly similar at South Georgia in autumn, although predation on Metridia spp. is higher (34\%M), with fewer Thysanoessa spp. consumed (13\%M) (Shreeve et al., 2009). The mysiid Antarctomysis spp. is also present in its diet during this time around South Georgia.

The diet of $G$. nicholsi (165 $\mathrm{mm} \mathrm{SL}_{\text {max. }}$ ) is dominated by krill (62\%M), R. gigas (11\%M), Thysanoessa spp. (8\%M), and T. gaudichaudii $(6 \% \mathrm{M})$ across the Scotia Sea, although krill are only consumed by specimens $>80 \mathrm{~mm}$ (Saunders et al., 2018). Similarly, T. gaudichaudii and euphausiids dominate its diet in autumn around South Georgia, particularly krill and Euphausia frigida (Shreeve et al., 2009). Data collected across multiple years and seasons at South Georgia also show that G. nicholsi consumes mostly euphausiids, with Thysanoessa spp. comprising substantial proportions of the identifiable component of this group (Oven et al., 1990). Deep water amphipods, fish and mysids, as well as copepods, are also important in its diet in this region. In waters further south around the South Shetland Island, G. nicholsi has a diet dominated by E. superba and other small euphausiids. The species also consume substantial proportions of fish in this region, including the myctophid $P$. bolini (Pusch et al., 2004), although these findings are mainly based on analysis of large specimens (>123 mm).

Little is known of the diet of G. opisthopterus $(187 \mathrm{~mm}$ $\mathrm{SL}_{\max }$ ), which occurs only in low abundance in the deepwater masses of the Scotia Sea. The available stomach contents data indicate that the species consumes krill, small euphausiids and amphipods, although sample sizes are low in the region (Saunders et al., 2015b). Information from biochemical dietary 
TABLE 2 | Diet of Electrona carlsbergi and Electrona antartica in the Scotia Sea expressed by percentage frequency of occurrence (\%F) and percentage mass (\%M).

\begin{tabular}{|c|c|c|c|c|c|c|c|c|}
\hline Location (date) & Season & $\begin{array}{c}\text { Depth } \mathrm{m} \\
\text { (no. samples) }\end{array}$ & SL (mm) & $\begin{array}{l}\text { Diet summary } \\
(\% \mathrm{~F}, \% \mathrm{M})\end{array}$ & Main prey taxa $(\% \mathrm{~F}, \% \mathrm{M})$ & & & \\
\hline \multicolumn{9}{|c|}{ Electrona carlsbergi } \\
\hline $\begin{array}{l}\text { Scotia Sea } \\
(2006-2009)^{1}\end{array}$ & Spring-Autumn & $\begin{array}{l}0-400 \\
(185)\end{array}$ & $65-90$ & $\begin{array}{l}\text { Copepod }(83,63) \\
\text { Euphausiid }(29,16) \\
\text { Amphipod }(12,8) \\
\text { Mollusk }(6,14)\end{array}$ & $\begin{array}{l}\text { Rhincalanus gigas }(70,50) \\
\text { Thysanoessa spp. }(11,6) \\
\text { Themisto gaudichaudii }(11,8) \\
\text { Unident. pteropods }(14,6)\end{array}$ & $\begin{array}{l}\text { Paraeuchaeta spp. }(22,4) \\
\text { Euphausia superba }(2,5)\end{array}$ & Metridia spp. $(48,2)$ & Triconia spp. $(28,2)$ \\
\hline $\begin{array}{l}\text { South Georgia } \\
(2004)^{2}\end{array}$ & Autumn & $\begin{array}{l}200-400 \\
(158)\end{array}$ & $71-93$ & $\begin{array}{l}\text { Crustacean }(41,27) \\
\text { Euphausiid }(21,33) \\
\text { Amphipod }(21,27) \\
\text { Copepod }(20,6)\end{array}$ & $\begin{array}{l}\text { Unident. crustaceans }(41,27) \\
\text { Unident. euphausiids }(15,25) \\
\text { Themisto gaudichaudii }(21,27) \\
\text { Rhincalanus gigas }(8,2)\end{array}$ & Euphausia superba $(2,7)$ & & \\
\hline \multicolumn{9}{|c|}{ Electrona antarctica } \\
\hline $\begin{array}{l}\text { Scotia Sea } \\
(2006-2009)^{1}\end{array}$ & Spring-Autumn & $\begin{array}{c}0-1000 \\
(485)\end{array}$ & $30-115$ & $\begin{array}{l}\text { Euphausiid }(36,61) \\
\text { Amphipod }(23,28) \\
\text { Copepod }(44,3) \\
\text { Mollusk }(6,4)\end{array}$ & $\begin{array}{l}\text { Euphausia superba }(15,51) \\
\text { Themisto gaudichaudii }(22,27) \\
\text { Metridia spp. }(27,1) \\
\text { Unident. pteropods }(5,3)\end{array}$ & Unident. euphausiids $(16,6)$ & & \\
\hline $\begin{array}{l}\text { Scotia Sea } \\
(1975-1976)^{3}\end{array}$ & Spring-Autumn & $\begin{array}{l}0-200 \\
(680)\end{array}$ & 22-103 & $\begin{array}{l}\text { Euphausiid }(22,71) \\
\text { Copepod }(25,5) \\
\text { Amphipods }(16,7) \\
\text { Mollusk }(8,3)\end{array}$ & $\begin{array}{l}\text { Euphausia superba }(22,54) \\
\text { Unident. copepods }(25,5) \\
\text { Unident. amphipods }(16,7) \\
\text { Unident. pteropods }(8,3)\end{array}$ & Other euphausiids $(27,17)$ & & \\
\hline $\begin{array}{l}\text { South Georgia } \\
(2004)^{2}\end{array}$ & Autumn & $\begin{array}{c}0-1000 \\
(126)\end{array}$ & $47-112$ & $\begin{array}{l}\text { Amphipod }(84,81) \\
\text { Euphausiid }(12,16) \\
\text { Crustacean }(6,2)\end{array}$ & $\begin{array}{l}\text { Themisto gaudichaudii }(84,81) \\
\text { Euphausia superba }(2,5) \\
\text { Unident. crustaceans }(6,2)\end{array}$ & Unident. euphausiids $(5,4)$ & & \\
\hline $\begin{array}{l}\text { South Shetlands } \\
(1996)^{4}\end{array}$ & Summer & $\begin{array}{c}200-800 \\
(61)\end{array}$ & $57-113$ & $\begin{array}{l}\text { Euphausiid }\left(66,85^{*}\right) \\
\text { Amphipod }\left(2,14^{*}\right)\end{array}$ & $\begin{array}{l}\text { Euphausia superba (na, 53*) } \\
\text { Unident. amphipods }\left(2,14^{*}\right)\end{array}$ & Euphausia spp. (na, 28*) & & \\
\hline $\begin{array}{l}\text { Antarctic zone } \\
(1985-1995)^{5}\end{array}$ & Summer-Autumn & $\begin{array}{c}0-300 \\
(52)\end{array}$ & $25-85$ & $\begin{array}{l}\text { Copepod }(75 \% \mathrm{~N}) \\
\text { Chaetognath }(8 \% \mathrm{~N}) \\
\text { Euphausiid }(6 \% \mathrm{~N})\end{array}$ & $\begin{array}{l}\text { Metridia gerlachei }(25 \% \mathrm{~N}) \\
\text { Eukrohma hameta }(4 \% \mathrm{~N}) \\
\text { Thysanoessa macrura }(4 \% \mathrm{~N})\end{array}$ & $\begin{array}{l}\text { Calanus propinquus }(21 \% \mathrm{~N}) \\
\text { Unident. chaetognaths }(3 \% \mathrm{~N})\end{array}$ & $\begin{array}{l}\text { Calanoida spp. }(8 \% \mathrm{~N}) \\
\text { Sagitta spp. }(2 \% \mathrm{~N})\end{array}$ & Calanoides acutus $(5 \% \mathrm{~N})$ \\
\hline
\end{tabular}

Percentage number $(\% \mathrm{~N})$ is given where other metrics were unavailable. All masses are wet weight except those denoted (*), which are reconstructed dry weights. Instances where diet metrics were not available are denoted (na). Specimen body sizes are in Standard Length (SL, mm). Data taken from ${ }^{1}$ Saunders et al. (2014), ${ }^{2}$ Shreeve et al. (2009), ${ }^{3}$ Rowedder (1979a), ${ }^{4}$ Pusch et al. (2004), and ${ }^{5}$ Pakhomov et al. (1996). 
TABLE 3 | Diet of Gymnoscopelus braueri, Gymnoscopelus fraseri, Gymnoscopelus nicholsi, and Gymnoscopelus opisthopterus in the Scotia Sea expressed by percentage frequency of occurrence (\%F) and percentage mass $(\% \mathrm{M})$.

\begin{tabular}{|c|c|c|c|c|c|c|c|c|}
\hline Location (date) & Season & $\begin{array}{c}\text { Depth m } \\
\text { (no. samples) }\end{array}$ & SL (mm) & $\begin{array}{l}\text { Diet summary } \\
(\% \mathrm{~F}, \% \mathrm{M})\end{array}$ & Main prey taxa $(\% \mathrm{~F}, \% \mathrm{M})$ & & & \\
\hline \multicolumn{9}{|c|}{ Gymnoscopelus braueri } \\
\hline $\begin{array}{l}\text { Scotia Sea } \\
(2006-2009)^{1}\end{array}$ & $\begin{array}{l}\text { Spring- } \\
\text { Autumn }\end{array}$ & $\begin{array}{l}0-1000 \\
(372)\end{array}$ & $30-142$ & $\begin{array}{l}\text { Euphausiid }(41,58) \\
\text { Amphipod }(9,18)\end{array}$ & $\begin{array}{l}\text { Euphausia superba }(5,20) \\
\text { Themisto gaudichaudii }(8,16)\end{array}$ & Thysanoessa spp. $(23,15)$ & Unident. euphausiids $(10,10)$ & Euphausia triacantha $(2,10)$ \\
\hline & & & & Copepod $(64,16)$ & Metridia spp. $(35,4)$ & Rhincalanus gigas $(15,5)$ & & \\
\hline $\begin{array}{l}\text { South Georgia } \\
(2004)^{2}\end{array}$ & Autumn & $\begin{array}{c}0-1000 \\
(98)\end{array}$ & $46-133$ & $\begin{array}{l}\text { Amphipod }(48,44) \\
\text { Euphausiid }(28,42) \\
\text { Mysiid }(22,7) \\
\text { Copepod }(16,3)\end{array}$ & $\begin{array}{l}\text { Themisto gaudichaudii }(48,44) \\
\text { Euphausia superba }(11,37) \\
\text { Antarctomysis spp. }(22,7) \\
\text { Rhincalanus gigas }(8,1)\end{array}$ & & & \\
\hline $\begin{array}{l}\text { South Shetlands } \\
(1996)^{3}\end{array}$ & Summer & $\begin{array}{c}200-800 \\
(21)\end{array}$ & $69-121$ & $\begin{array}{l}\text { Euphausiid }\left(61,75^{*}\right) \\
\text { Amphipod }\left(7,24^{*}\right)\end{array}$ & $\begin{array}{l}\text { Euphausia spp. (na, 65*) } \\
\text { Unident. amphipods (na, 24*) }\end{array}$ & Euphausia triacantha (na, 10*) & & \\
\hline \multicolumn{9}{|c|}{ Gymnoscopelus fraseri } \\
\hline $\begin{array}{l}\text { Scotia Sea } \\
(2006-2009)^{1}\end{array}$ & $\begin{array}{l}\text { Spring- } \\
\text { Autumn }\end{array}$ & $\begin{array}{l}0-700 \\
(103)\end{array}$ & $35-115$ & $\begin{array}{l}\text { Copepod }(93,41) \\
\text { Euphausiid }(54,39) \\
\text { Amphipod }(12,17)\end{array}$ & $\begin{array}{l}\text { Metridia spp. }(81,19) \\
\text { Thysanoessa spp. }(52,39) \\
\text { Themisto gaudichaudii }(11,16)\end{array}$ & Rhincalanus gigas $(49,11)$ & Pleuromamma robusta $(44,5)$ & \\
\hline $\begin{array}{l}\text { South Georgia } \\
(2004)^{2}\end{array}$ & Autumn & $\begin{array}{c}0-600 \\
(56)\end{array}$ & $46-112$ & $\begin{array}{l}\text { Copepod }(50,58) \\
\text { Euphausiid }(38,26) \\
\text { Amphipod }(9,8) \\
\text { Mysiid }(20,8)\end{array}$ & $\begin{array}{l}\text { Metridia spp. }(41,34) \\
\text { Thysanoessa spp. }(7,13) \\
\text { Themisto gaudichaudii }(9,8) \\
\text { Antarctomysis spp. }(20,8)\end{array}$ & $\begin{array}{l}\text { Rhincalanus gigas }(25,12) \\
\text { Unident. euphausiids }(20,9)\end{array}$ & Paraeuchaeta spp. $(9,4)$ & \\
\hline \multicolumn{9}{|c|}{ Gymnoscopelus nicholsi } \\
\hline $\begin{array}{l}\text { Scotia Sea } \\
(2006-2009)^{1}\end{array}$ & $\begin{array}{l}\text { Spring- } \\
\text { Autumn }\end{array}$ & $\begin{array}{c}0-1000 \\
(40)\end{array}$ & $35-165$ & $\begin{array}{l}\text { Euphausiid }(68,75) \\
\text { Copepod }(90,19) \\
\text { Amphipod }(23,6)\end{array}$ & $\begin{array}{l}\text { Euphausia superba }(20,62) \\
\text { Rhincalanus gigas }(53,10) \\
\text { Themisto gaudichaudii }(2,6)\end{array}$ & $\begin{array}{l}\text { Thysanoessa spp. }(45,8) \\
\text { Pleuromamma robusta }(43,3)\end{array}$ & Metridia spp. $(80,3)$ & \\
\hline $\begin{array}{l}\text { South Georgia } \\
(2004)^{2}\end{array}$ & Autumn & $\begin{array}{c}0-600 \\
(89)\end{array}$ & $52-112$ & $\begin{array}{l}\text { Euphausiid }(56,56) \\
\text { Amphipod }(25,29) \\
\text { Mysiid }(16,7) \\
\text { Copepod }(44,6)\end{array}$ & $\begin{array}{l}\text { Euphausia superba }(7,23) \\
\text { Themisto gaudichaudii }(25,29) \\
\text { Antarctomysis spp. }(16,7) \\
\text { Metridia spp. }(36,2)\end{array}$ & Euphausia frigida $(20,15)$ & Unident. euphausiids $(20,12)$ & Thysanoessa spp. $(16,7)$ \\
\hline $\begin{array}{l}\text { South Georgia } \\
(1979-1985)^{4}\end{array}$ & $\begin{array}{l}\text { Spring- } \\
\text { Autumn }\end{array}$ & $\begin{array}{c}20-420 \\
(60)\end{array}$ & $70-152$ & $\begin{array}{l}\text { Euphausiid }(38,53) \\
\text { Amphipod }(17,16) \\
\text { Copepod }(18,9) \\
\text { Pisces }(2,8) \\
\text { Mysiid }(10,7)\end{array}$ & $\begin{array}{l}\text { Unident. euphausiids }(30,41) \\
\text { Phronimidae spp. }(5,11) \\
\text { Unident. copepods }(13,8) \\
\text { Unident. fish }(2,8) \\
\text { Unident. mysiids }(10,7)\end{array}$ & $\begin{array}{l}\text { Thysanoessa spp. }(8,12) \\
\text { Unident. amphipods }(7,2)\end{array}$ & & \\
\hline $\begin{array}{l}\text { South Shetlands } \\
(1996)^{3}\end{array}$ & Summer & $\begin{array}{l}200-800 \\
(135)\end{array}$ & 123-172 & $\begin{array}{l}\text { Euphausiid }\left(\sim 65,78^{*}\right) \\
\text { Pisces }\left(10,14^{*}\right) \\
\text { Copepod }\left(78,4^{*}\right) \\
\text { Chaetognath }\left(5,4^{*}\right)\end{array}$ & $\begin{array}{l}\text { Euphausia superba (na, 58*) } \\
\text { Protomyctophum bolini (na, } 7^{*} \text { ) } \\
\text { Metridia gerlachei (na, } 2^{*} \text { ) } \\
\text { Unident. chaetognaths (na, 48*) }\end{array}$ & $\begin{array}{l}\text { Thysanoessa macrura (na, 10*) } \\
\text { Neopageotopsis ionah (na, 6*) }\end{array}$ & Euphausia spp. (na, 6*) & \\
\hline \multicolumn{9}{|c|}{ Gymnoscopelus opisthopterus } \\
\hline $\begin{array}{l}\text { Antarctic zone } \\
(1985-1995)^{5}\end{array}$ & $\begin{array}{l}\text { Summer- } \\
\text { Autumn }\end{array}$ & $\begin{array}{c}0-300 \\
(32)\end{array}$ & $64-154$ & $\begin{array}{l}\text { Euphausiid }(45 \% \mathrm{~N}) \\
\text { Copepod }(17 \% \mathrm{~N}) \\
\text { Salp }(11 \% \mathrm{~N}) \\
\text { Pisces }(14 \% \mathrm{~N})\end{array}$ & $\begin{array}{l}\text { Euphausia superba }(17 \% \mathrm{~N}) \\
\text { Paraeuchaeta antarctica }(14 \% \mathrm{~N}) \\
\text { Salpa thompsoni }(11 \% \mathrm{~N}) \\
\text { Unident. fish scales }(14 \% \mathrm{~N})\end{array}$ & Euphausia furcillia (17\%N) & Unident. euphausiids (11\%N) & \\
\hline
\end{tabular}


TABLE 4 | Diet of Protomyctophum bolini, Protomyctophum choriodon, and Protomyctophum tenisoni in the Scotia Sea expressed by percentage frequency of occurrence (\%F) and percentage mass (\%M).

\begin{tabular}{|c|c|c|c|c|c|c|c|c|}
\hline Location (date) & Season & $\begin{array}{c}\text { Depth m } \\
\text { (no. samples) }\end{array}$ & SL (mm) & $\begin{array}{l}\text { Diet summary } \\
(\% \mathrm{~F}, \% \mathrm{M})\end{array}$ & Main prey taxa $(\% \mathrm{~F}, \% \mathrm{M})$ & & & \\
\hline \multicolumn{9}{|c|}{ Protomyctophum bolini } \\
\hline \multirow{3}{*}{$\begin{array}{l}\text { Scotia Sea } \\
(2006-2009)^{1}\end{array}$} & Spring-Autumn & $0-400$ & $25-70$ & Copepod $(84,70)$ & Metridia spp. $(46,21)$ & Rhincalanus gigas $(45,31)$ & Paraeuchaeta spp. $(23,9)$ & \\
\hline & & (231) & & Euphausiid $(29,26)$ & Thysanoessa spp. $(17,17)$ & Unident. euphausiids $(11,6)$ & & \\
\hline & & & & Crustacean $(11,3)$ & Unident. crustaceans $(11,3)$ & & & \\
\hline \multirow{3}{*}{$\begin{array}{l}\text { South Georgia } \\
(2004)^{2}\end{array}$} & Autumn & $0-400$ & $38-78$ & Euphausiid $(44,52)$ & Euphausia frigida $(23,34)$ & Unident. euphausiids $(15,12)$ & Thysanoessa spp. $(10,6)$ & \\
\hline & & (61) & & Crustacean $(46,34)$ & Unident. crustaceans $(46,34)$ & & & \\
\hline & & & & Copepod $(31,13)$ & Metridia spp. $(19,4)$ & Paraeuchaeta spp. $(5,3)$ & & \\
\hline \multirow{2}{*}{$\begin{array}{l}\text { South Shetlands } \\
(1996)^{3}\end{array}$} & Summer & $200-800$ & $33-53$ & Copepod $\left(90,84^{*}\right)$ & Metridia gerlachei (na, 76*) & Paraeuchaeta spp. (na, $4^{*}$ ) & & \\
\hline & & $(101)$ & & Euphausiid $(8,13)$ & Thysanoessa macrura (na, 13*) & & & \\
\hline \multicolumn{9}{|c|}{ Protomyctophum choriodon } \\
\hline & Spring-Autumn & $0-700$ & & Euphausiid $(68,48)$ & Thysanoessa spp. $(65,47)$ & & & \\
\hline \multirow{2}{*}{$\begin{array}{l}\text { Scotla Sea } \\
(2006-2009)^{1}\end{array}$} & & (37) & & Copepod $(78,32)$ & Rhincalanus gigas $(62,17)$ & Calanus simillimus $(32,9)$ & Metridia spp. $(43,5)$ & \\
\hline & & & & Amphipod $(35,16)$ & Themisto gaudichaudii $(32,13)$ & & & \\
\hline \multirow{4}{*}{$\begin{array}{l}\text { South Georgia } \\
(2004)^{2}\end{array}$} & Autumn & 0-400 & $51-85$ & Copepod $(54,60)$ & Calanoides acutus $(33,22)$ & Metridia spp. $(44,12)$ & Rhincalanus gigas $(30,13)$ & \\
\hline & & (61) & & Crustacean $(35,18)$ & Unident. crustaceans $(34,18)$ & & & \\
\hline & & & & Euphausiid $(37,15)$ & Unident. euphausiids $(37,15)$ & Thysanoessa spp. $(24,8)$ & & \\
\hline & & & & Amphipod $(14,5)$ & Themisto gaudichaudii $(14,5)$ & & & \\
\hline \multirow{4}{*}{$\begin{array}{l}\text { Argentine Basin and } \\
\text { South Georgia } \\
(1979-1985)^{4}\end{array}$} & Spring-Autumn & $20-420$ & $55-90$ & Copepod (na, 41) & Unident. copepods $(59,27)$ & Calanus spp. $(23,10)$ & & \\
\hline & & (72) & & Amphipod (na, 31) & Pronoidae spp. $(9,11)$ & Unident. amphipods $(9,9)$ & Phronimidae spp. $(5,5)$ & Vibiliidae spp. $(5,5)$ \\
\hline & & & & Bivalve (na, 16) & Protobranchia atlanta $(18,16)$ & & & \\
\hline & & & & Decapod (na) & Lucifer typicus $(23,8)$ & & & \\
\hline \multicolumn{9}{|c|}{ Protomyctophum tenisoni } \\
\hline Scotia Sea & Spring-Autumn & $0-400$ & $32-55$ & Copepod $(83,61)$ & Calanus simillimus $(57,38)$ & Rhincalanus gigas $(28,12)$ & Metridia spp. $(30,6)$ & \\
\hline \multirow[t]{3}{*}{$(2006-2009)^{1}$} & & $(46)$ & & Euphausiid $(43,26)$ & Thysanoessa spp. $(30,22)$ & & & \\
\hline & & & & Amphipod $(9,6)$ & Themisto gaudichaudii $(9,6)$ & & & \\
\hline & & & & Pisces $(2,5)$ & Unident. fish $(2,5)$ & & & \\
\hline
\end{tabular}

Percentage number $(\% \mathrm{~N})$ is given where other metrics were unavailable. All masses are wet weight except those denoted $\left.{ }^{*}\right)$, which are reconstructed dry weights. Instances where diet metrics were not available are denoted (na). Specimen body sizes are in Standard Length (SL, mm). Data taken from ${ }^{1}$ Saunders et al. (2015c), ${ }^{2}$ Shreeve et al. (2009), ${ }^{3}$ Pusch et al. (2004), and ${ }^{4}$ Oven et al. (1990). 


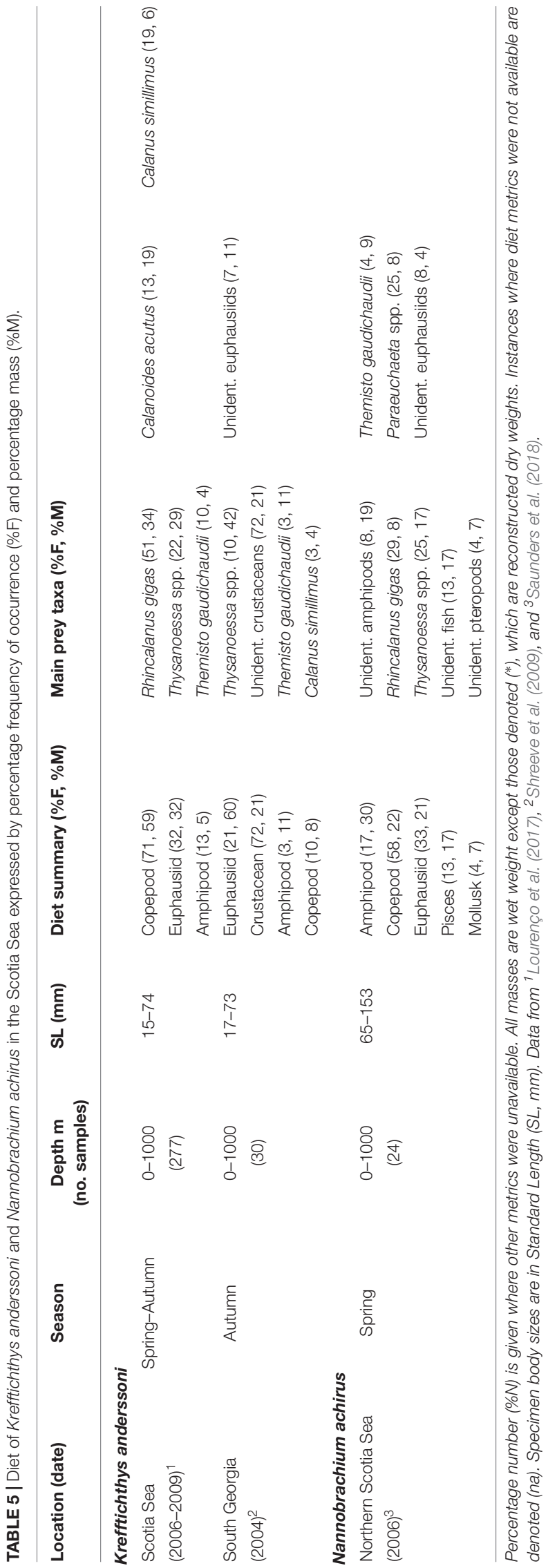

studies in the Southern Ocean also suggest that it consumes mostly macroplankton, such as the euphausiid E. superba (Phleger et al., 1999).

\section{Protomyctophum Diet Composition}

Protomyctophum bolini (78 $\mathrm{mm} \quad \mathrm{SL}_{\max }$ ) predominantly consumes copepods and small euphausiids in the Scotia Sea (Table 4). R. gigas, Metridia spp., and Thysanoessa spp. are its dominant prey species based on data collected over the entire Scotia Sea (Saunders et al., 2015c), although Euphausia frigida and unidentified crustaceans are more prevalent in its diet at South Georgia in autumn (Shreeve et al., 2009). Around the South Shetland Islands, the diet of P. bolini is dominated by copepods, particularly Metridia gerlachei (76\%M) (Pusch et al., 2004). Although the sizes of specimens collected in the region were relatively small $(<53 \mathrm{~mm})$, Thysanoessa spp. appears to be an important dietary component in this region $(10 \% \mathrm{M})$.

The diet of $P$. choriodon ( $85 \mathrm{~mm} \mathrm{SL}$ max.) comprises mostly Thysanoessa spp., R. gigas, T. gaudichaudii, and Calanus simillimus across the northern Scotia Sea. However, its diet at South Georgia in autumn comprises predominantly copepods, including Calanoides acutus, R. gigas, and Metridia spp., together with crustaceans and euphausiids that could not be identified more resolutely. The only other quantitative data available on the diet of this myctophid species integrates data from sampling sites at South Georgia and the Argentine Basin over multiple seasons and years, and therefore lacks temporal and spatial resolution (Oven et al., 1990). However, the data demonstrate that P. choriodon is an opportunistic feeder, which consumes mostly copepods and macroplankton, including various amphipods and decapods. The presence of bivalves in its diet also suggests both benthic and surface feeding in the species (Oven et al., 1990).

The few data that exists on the feeding ecology of $P$. tenisoni indicate that it consumes mostly the copepods C. simillimus, R. gigas, and Thysanoessa spp. in the Scotia Sea (Saunders et al., 2015c), the latter two prey species taken predominantly by fish $>40 \mathrm{~mm}$ (Saunders et al., 2018). The amphipod T. gaudichaudii and unidentified fish also occur in the diet of these larger size classes.

\section{Other Species Diet Composition}

The diet of $K$. anderssoni (75 $\mathrm{mm} \mathrm{SL}_{\text {max. }}$ ) is comprised mostly of the copepods $R$. gigas, C. acutus and small euphausiids of the Thysanoessa genus throughout its distribution in the northern Scotia Sea (Lourenço et al., 2017) (Table 5). Specimens $>60 \mathrm{~mm}$ also consume small proportions of T. gaudichaudii and large proportions of Thysanoessa spp., although these small euphausiids are absent in the diet of specimens $<40 \mathrm{~mm}$. Data from more limited sample sizes at South Georgia also show that $K$. anderssoni consumes substantial proportions of Thysanoessa spp. and T. gaudichaudii in autumn, with copepods less dominant in its diet (Shreeve et al., 2009). This seasonal switch in diet is similar to that observed at a broader spatial scale across the northern Scotia Sea (Lourenço et al., 2017).

Data collected in the northern Scotia Sea in spring indicate that $N$. achirus (167 $\mathrm{mm} \mathrm{SL}$ max. ) consumes mostly amphipods, with unidentified deep-dwelling species comprising the greatest 
proportion of this dietary group (Saunders et al., 2018) (Table 5). The copepods $R$. gigas and Pareuchaeta spp., as well as the small euphausiid Thysanoessa spp. and unidentified fish are also important in the species diet.

\section{PREDATORY IMPACT OF MYCTOPHIDS ON SCOTIA SEA ZOOPLANKTON}

\section{Predation Estimates on Daily Zooplankton Productivity}

Contemporary studies of the predatory impact of myctophids on the underlying zooplankton community in the Scotia Sea indicate that, although there is a major flux of secondary productivity passing through myctophids, they seldom exhaust their prey field in the Scotia Sea and species appear not to be in direct competition for resources (Shreeve et al., 2009; Saunders et al., 2015a, 2018). The level of myctophid predation on the daily growth production of copepods was conservatively estimated to be $<1 \%$ (in terms of $\mathrm{C} \mathrm{m}^{-2} \mathrm{day}^{-1}$ ) around South Georgia in autumn (Shreeve et al., 2009). Similarly, myctophids were estimated to consume $<5 \%$ of the daily productivity of copepods across the Scotia Sea based on data averaged over different seasons, although an estimate of up to $11 \%$ is more likely once zooplankton production values are adjusted to ambient temperatures of the Scotia Sea (Table 6; see Saunders et al., 2018). Copepod consumption by myctophids in different seasons was predominately $<7 \%$ of daily productivity across the Scotia Sea, although C. simillimus was predated upon highly in summer ( $\sim 26 \%$ of daily productivity) (Saunders et al., 2018 ).

Of the macrozooplankton component of the myctophid diets, the small euphausiid Thysanoessa spp. was impacted the most throughout the Scotia Sea, with up 28\% of its daily productivity consumed, based on data integrated over different seasons (Table 6). However, the predatory impact on this species may be as high as $\sim 76 \%$ of its daily productivity in summer (Saunders et al., 2018). Collectively, the predatory impact of large myctophids on the daily productivity of Antarctic krill was around $6 \%$ over the entire Scotia Sea and up to $\sim 14 \%$ at South Georgia in autumn, once production estimates were rescaled to ambient temperatures (Shreeve et al., 2009; Saunders et al., 2015a). These estimates were similar to those across the Scotia Sea in spring $(\sim 10 \%$ daily productivity) and autumn ( $\sim 8 \%$ daily productivity), although myctophid predation on the daily productivity of krill was as high as $56 \%$ in the region during summer (Saunders et al., 2018). The large myctophids also had a substantial impact on T. gaudichaudii throughout the Scotia Sea, consuming around $9 \%$ of its daily productivity overall (Saunders et al., 2015a). Seasonal estimates of the predatory impact of myctophids on this species were between 10 and $38 \%$ (daily productivity), with the greatest levels of impact in spring (Saunders et al., 2018). Similar values were reported at South Georgia in autumn ( $\sim 9 \%$ daily productivity with revised production estimates) (Shreeve et al., 2009). Overall, myctophid predation on the daily productivity of salps was relatively low (up to $4 \%$ in summer), whilst their impact on ostracods and pteropods was negligible $(<0.1 \%$ of daily productivity) in all seasons.

\section{Annual Consumption Estimates}

Estimates of daily rations, together with synoptic estimates of both myctophid and prey abundance and data on myctophid diet compositions, have been used in various calculations of the annual removal of zooplankton, particularly krill, at the scale of the Scotia Sea and the Southern Ocean (Naumov, 1985; Pakhomov et al., 1996; Pusch et al., 2004; Hill et al., 2007; Collins et al., 2012; Kock et al., 2012; Saunders et al., 2015a). Based on data collected in the Scotia Sea, Rowedder (1979a) estimated daily rations for E. antarctica to be around 5\% of dry body weight, although this is considered to represent an overestimate because of the bias associated with the extrapolation to the entire year of levels of food intake obtained during summer and within a region of high Antarctic krill biomass (Pakhomov et al., 1996). Gerasimova (1990) calculated daily rations for E. carlsbergi in the Scotia Sea using an energy budget approach and estimated that it requires between 3.7 to $5.6 \%$ of wet body weight daily, or 2.5 to 3.7\% of its dry body weight. Pakhomov et al. (1996) investigated daily rations of myctophids using data from different regions of the Southern Ocean (including the Scotia Sea) and reported that daily food intake ranged between 0.2 and $4.4 \%$ of dry body weight, with mean values between 0.5 to $2.9 \%$ of dry body weight for the Antarctic and sub-Antarctic species, E. antarctica, E. carlsbergi, G. nicholsi, and G. opisthopterus. These estimates were in good agreement with those of Pusch et al. (2004) who estimated daily rations of between 0.7 and $3.3 \%$ of dry body weight at the South Shetland Islands, assuming a $24 \mathrm{~h}$ feeding period for E. antarctica, G. braueri, G. nicholsi, and P. bolini.

Around the South Shetland Islands, Pusch et al. (2004) estimated that the annual removal of krill by E. antarctica and G. nicholsi was around 11.4 and $27.4 \mathrm{Mt}$, which equated to 11.1$26.7 \%$ of the total krill stock in the region. These parameter estimates were further extrapolated over a wider spatial scale by Hill et al. (2007), who estimated that the total demand for krill by myctophids in the Scotia Sea was $20.5 \mathrm{Mt}$ (of a total of $25.2 \mathrm{Mt}$ across the Scotia Sea - Antarctic Peninsula region). However, these studies did not account for seasonal and spatial variability in consumption, myctophid abundance and krill biomass across the region. More comprehensive myctophid biomass data were collected across the entire Scotia Sea in different seasons by Collins et al. (2012), who estimated that myctophids consume approximately $25 \mathrm{Mt}$ of macro-zooplankton per year, assuming that myctophids consume an average of $1.5 \%$ body weight per day (Pakhomov et al., 1996). Saunders et al. (2015a) subsequently partitioned this overall estimate of consumption by individual prey taxa using concurrent trophodynamics data for the biomass dominant myctophid species in the region (Table 6). The study reported that large myctophids, principally E. antarctica, G. nicholsi, and G. braueri, consumed around 16.8 Mt of krill annually, further supporting the hypothesis that large myctophids are major predators of this species at both a regional and ocean-basin scale (Rowedder, 1979a; Lancraft et al., 1989; Pusch et al., 2004; Hill et al., 2007; Kock et al., 2012). Total annual consumption of copepods, Thysanoessa 
TABLE 6 | Best (median) estimates of the overall impact of myctophid predation on the productivity of their main zooplankton prey taxa in the Scotia Sea, expressed as a percentage of the daily production consumed $\left(\mu \mathrm{g} \mathrm{m}^{-1}\right.$ day $\left.^{-1}\right)$ by each myctophid species.

\begin{tabular}{|c|c|c|c|c|c|c|c|c|c|c|c|c|c|c|}
\hline $\begin{array}{l}\text { Myctophid } \\
\text { species }\end{array}$ & $\begin{array}{c}\text { Themisto } \\
\text { gaudichaudii }\end{array}$ & $\begin{array}{c}\text { Euphausia } \\
\text { frigida }\end{array}$ & $\begin{array}{l}\text { Euphausia } \\
\text { superba }\end{array}$ & $\begin{array}{l}\text { Thysanoessa } \\
\text { spp. }\end{array}$ & $\begin{array}{l}\text { Calanoides } \\
\text { acutus }\end{array}$ & $\begin{array}{l}\text { Calanus } \\
\text { simillimus }\end{array}$ & $\begin{array}{l}\text { Metridia } \\
\text { spp. }\end{array}$ & $\begin{array}{l}\text { Triconia } \\
\text { spp. }\end{array}$ & $\begin{array}{l}\text { Pleuromamma } \\
\text { robusta }\end{array}$ & $\begin{array}{l}\text { Paraeuchaeta } \\
\text { spp. }\end{array}$ & $\begin{array}{l}\text { Rhincalanus } \\
\text { gigas }\end{array}$ & Ostracods & Pteropods & Salps \\
\hline $\begin{array}{l}\text { Electrona } \\
\text { carlsbergi }\end{array}$ & 0.38 & 0.00 & 0.00 & 0.74 & 0.01 & 0.41 & 0.02 & 0.02 & 0.00 & 0.31 & 1.83 & 0.00 & 0.00 & 0.23 \\
\hline $\begin{array}{l}\text { Electrona } \\
\text { antarctica }\end{array}$ & 6.33 & 0.00 & 5.21 & 1.88 & 0.04 & 0.16 & 0.06 & 0.00 & 0.00 & 0.63 & 0.14 & 0.05 & 0.00 & 0.00 \\
\hline $\begin{array}{l}\text { Gymnoscopelus } \\
\text { fraseri }\end{array}$ & 0.07 & 0.00 & 0.00 & 2.06 & 0.01 & 0.21 & 0.04 & 0.00 & 0.00 & 0.03 & 0.10 & 0.01 & 0.00 & 0.00 \\
\hline $\begin{array}{l}\text { Gymnoscopelus } \\
\text { nicholsi }\end{array}$ & 0.11 & 0.53 & 0.11 & 0.72 & 0.01 & 0.04 & 0.02 & 0.00 & 0.01 & 0.07 & 0.35 & 0.00 & 0.00 & 0.01 \\
\hline $\begin{array}{l}\text { Gymnoscopelus } \\
\text { braueri }\end{array}$ & 0.56 & 0.00 & 0.41 & 4.28 & 0.02 & 0.32 & 0.06 & 0.00 & 0.01 & 0.21 & 0.16 & 0.04 & 0.00 & 0.00 \\
\hline $\begin{array}{l}\text { Krefftichthys } \\
\text { anderssoni }\end{array}$ & 1.20 & 0.00 & 0.00 & 13.93 & 2.33 & 4.64 & 0.03 & 0.00 & 0.00 & 0.05 & 3.55 & 0.00 & 0.00 & 0.00 \\
\hline $\begin{array}{l}\text { Nannobrachium } \\
\text { achirus }\end{array}$ & 0.02 & 0.00 & 0.00 & 0.42 & 0.00 & 0.05 & 0.00 & 0.00 & 0.00 & 0.08 & 0.03 & 0.00 & 0.00 & 0.00 \\
\hline $\begin{array}{l}\text { Protomyctophum } \\
\text { tenisoni }\end{array}$ & 0.17 & 0.00 & 0.00 & 0.67 & 0.01 & 3.60 & 0.01 & 0.00 & 0.00 & 0.03 & 0.04 & 0.00 & 0.00 & 0.00 \\
\hline $\begin{array}{l}\text { Protomyctophum } \\
\text { bolini }\end{array}$ & 0.00 & 0.00 & 0.00 & 1.36 & 0.00 & 0.07 & 0.14 & 0.00 & 0.01 & 0.48 & 0.83 & 0.01 & 0.00 & 0.00 \\
\hline $\begin{array}{l}\text { Protomyctophum } \\
\text { choriodon }\end{array}$ & 0.28 & 0.00 & 0.00 & 2.21 & 0.01 & 1.31 & 0.01 & 0.00 & 0.00 & 0.01 & 0.15 & 0.00 & 0.00 & 0.00 \\
\hline Total & 9.13 & 0.53 & 5.72 & 28.27 & 2.44 & 10.81 & 0.39 & 0.02 & 0.04 & 1.89 & 7.17 & 0.12 & 0.00 & 0.24 \\
\hline $\begin{array}{l}\text { Total annual } \\
\text { consumption for } \\
\text { the Scotia Sea }\end{array}$ & $2,245,883$ & 14,120 & $16,808,493$ & $3,754,095$ & 110,723 & 47,305 & 176,078 & 121 & 28,136 & 95,922 & $1,135,180$ & 1,083 & 140 & 220,222 \\
\hline
\end{tabular}


spp. and T. gaudichaudii was around 1.5, 4, and $2 \mathrm{Mt}$ per year, respectively.

\section{REFINING THE ROLE OF MYCTOPHIDS IN THE OPERATION OF THE SCOTIA SEA FOOD WEB}

\section{Myctophids as Predators of Krill}

Krill are absent from the diets of the small Protomyctophum species and $K$. anderssoni in all seasons, which mostly reflects their inability to handle the relatively large $(>40 \mathrm{~mm})$ sized sub-adult and adult krill stages that occur predominantly in the northern Scotia Sea, where these myctophids were mostly distributed. Furthermore, these small myctophids seldom penetrate the cold waters of the sea ice zone where the early life stages $(<30 \mathrm{~mm})$ of krill are most prevalent in the prey field. The principle prey of these smaller myctophid species were copepods and small euphausiids. Although the myctophid species G. fraseri, E. carlsbergi and N. achirus attained a body size sufficient for handling krill within their distributional range, it was also largely absent from their diets. Only the large myctophids E. antarctica, G. nicholsi, and $G$. braueri consistently consumed krill across the Scotia Sea and in different seasons. Collectively, these findings support the concept that myctophids, particularly the small species, can provide an important trophic link between secondary production and higher predators that is largely independent of krill. However, they also highlight that large myctophid species consume substantial proportions of krill, both in different seasons and across their distributional range, which may amount to large amounts of krill being removed by these fish on an annual basis.

Although krill consumption per unit myctophid biomass may be relatively low (Hill et al., 2007), the data indicate that these fish remain major consumers of krill due to their relatively high biomass and broad-scale distributions patterns. Therefore, contrary to popular belief that air breathing higher predators are the most prevalent consumers of krill (Boyd, 2002a), the data collectively support the hypothesis that myctophids are the greatest predators of krill in the Scotia Sea ecosystem (Hill et al., 2007; Kock et al., 2012), consuming around 16.8 Mt per year. This exceeds the total estimated demand for krill by other fish, birds and mammals ( 13.7 Mt per year) (Table 7$)$. Estimates of krill consumption by other perciformes, primarily demersal species, also indicate that demersal fish are substantial predators of krill in the Scotia Sea - Antarctic Peninsula region (Hill et al., 2007; Kock et al., 2012). Overall, based on current best estimates, myctophids appear to be responsible for around $55-60 \%$ of krill consumption by vertebrates in the Scotia Sea and slightly less $(\sim 52 \%)$ in the greater Scotia Sea - Antarctic Peninsula region. Overall, this annual consumption by vertebrate predators is $\sim 61.3 \mathrm{Mt}$, which is a relatively close match to the estimated krill biomass in 2000 (57.7 Mt) (Hill et al., 2016). Consequently, large myctophids need to be considered as major predators of krill and, along with the small non-krill consuming
TABLE 7 | Summary of the current estimates of annual consumption of krill (million tonnes per year) in the Scotia Sea region by the main krill predators, showing the $\%$ contribution of myctophids to the total.

\begin{tabular}{|c|c|c|c|}
\hline \multirow[t]{2}{*}{ Krill predator } & \multicolumn{2}{|c|}{ Demand for krill (Mt year-1) } & \multirow[t]{2}{*}{ Source } \\
\hline & Scotia Sea & $\begin{array}{c}\text { Scotia Sea - } \\
\text { Antarctic } \\
\text { Peninsula }\end{array}$ & \\
\hline Myctophid fish & 16.8 & - & Saunders et al., 2015a \\
\hline Myctophid fish & 20.5 & 25.2 & Hill et al., 2007 \\
\hline Myctophid fish & - & $5.0-32.0$ & Kock et al., 2012 \\
\hline Other fish & 2.5 & 12.1 & Hill et al., 2007 \\
\hline Penguins & 4.6 & 7.1 & Hill et al., 2007 \\
\hline Seals & 1.6 & 1.7 & Hill et al., 2007 \\
\hline Flying birds & 2.5 & - & Trathan and Hill, 2016 \\
\hline Crabeater seal & - & 4.5 & Boyd, 2002b \\
\hline Antarctic fur seal & 1.6 & 1.7 & Hill et al., 2007 \\
\hline Ice seals & - & 0.5 & Forcada et al., 2012 \\
\hline Whales & 0.9 & 1.7 & Hill et al., 2007 \\
\hline Total & $\sim 30.5$ to $\sim 34.2$ & $\sim 34.3$ to $\sim 61.3$ & \\
\hline $\begin{array}{l}\text { Myctophid } \\
\text { contribution }\end{array}$ & $\sim 55$ to $\sim 60 \%$ & $\sim 15$ to $\sim 52 \%$ & \\
\hline Est. krill biomass & 40.4 & 57.7 & Hill et al., 2016 \\
\hline
\end{tabular}

Estimates of krill biomass during 2000 are also included.

species (e.g., K. anderssoni and P. bolini), are an intricately linked part of the food web (Figure 3).

\section{Other Key Trophic Connections}

As well as identifying connections between krill- and myctophidbased trophic pathways in the Scotia Sea food web, contemporary trophodynamic studies provide further evidence that there are other important links in the myctophid-based pathway in the food web. For instance, small euphausiids, particularly those of the Thysanoessa genus, were consumed by all myctophid species across the Scotia Sea, comprising a major dietary component in many species, such as G. braueri, G. fraseri, $K$. anderssoni, and $P$. choriodon. Consumption of these small euphausiids was particularly marked in the northern Scotia Sea, which accord with observations from other sectors of the Southern Ocean, particularly around the sub-Antarctic Islands, where small euphausiids appear to replace Antarctic krill in myctophid diets due to their greater availability in the prey field (Murphy et al., 2007b; Ballerini et al., 2014). These small euphausiids are generally believed to consume mostly copepods, so it is clear that a major transfer of energy from secondary production to myctophids, and ultimately to higher predators, is passing through small euphausiids (Hopkins and Torres, 1989). There is also evidence that these small euphausiids are direct prey for several higher predator species, particularly penguins, sea birds and large predatory fish (Brown and Klages, 1987; Kock et al., 1994; Deagle et al., 2007; Pichegru et al., 2011). Euphausiids generally feed on both primary producers (e.g., Thysanoessa macrura on diatoms; Hopkins and Torres, 1989) and smaller zooplankton. Consequently, small euphausiids could be a direct conduit 
A

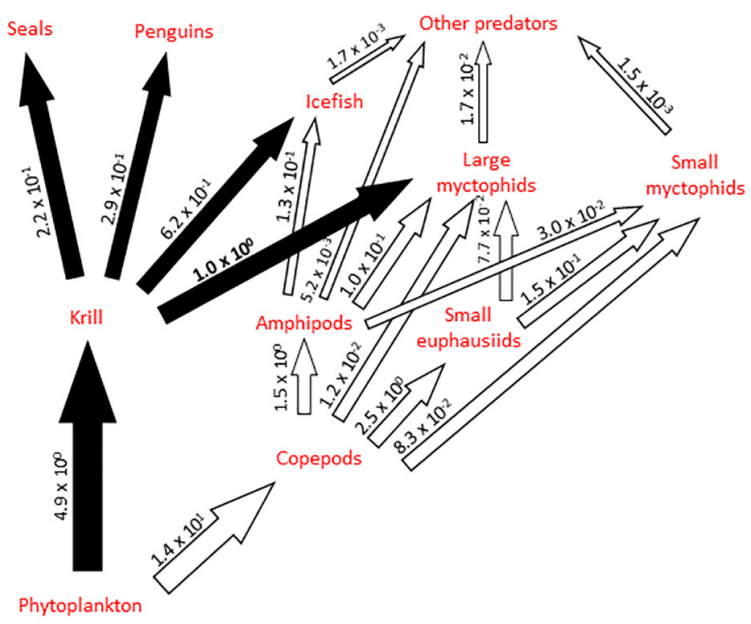

B

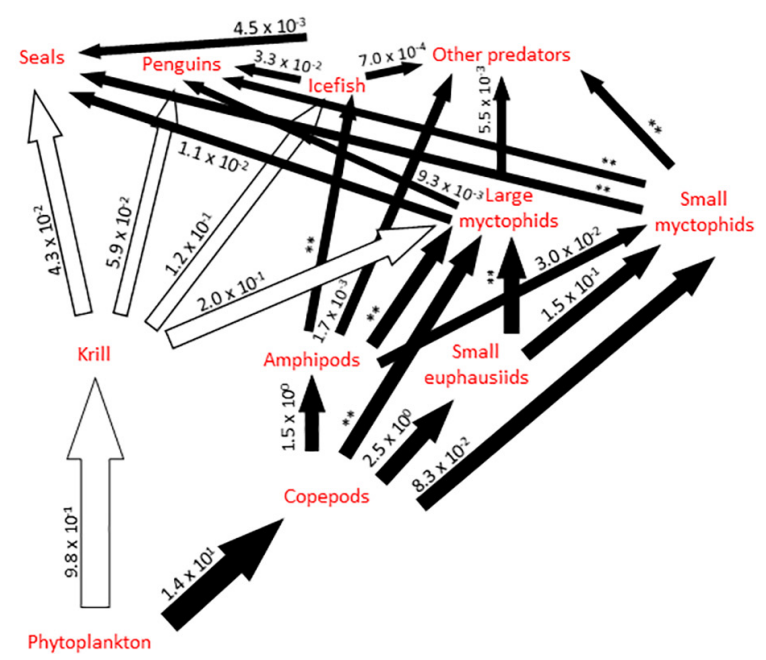

FIGURE 3 | Schematic illustration of alternative pathways in part of the Scotia Sea food web, highlighting the role of myctophids, showing shifts between years and regions where krill are (A) abundant (high krill scenario) and (B) scarce (low krill scenario). Major pathways are shown as black arrows, based on Murphy et al. (2007b) and modified to include information synthesized in this study. Preliminary estimates of biomass flow (scaled relative to krill consumption by large myctophids in a high krill scenario, which is estimated to be $16.8 \mathrm{Mt} \mathrm{year}^{-1}$ for the Scotia Sea; value in bold) illustrate the possible relative importance of the different trophic connections in the system under such scenarios. Values in panel (A) are derived from a food web model for the South Georgia shelf (Hill et al., 2012) updated with estimates of consumption by myctophids from Table $\mathbf{6}$. Values in panel (B) are derived from the same model after krill availability was reduced by $80 \%$. We have not recalculated values denoted $(* *)$ in scenario (B) as they require additional assumptions about how the predator populations in these links and their diets change in response to low krill abundance, which are beyond the scope of this illustrative model [see Hill et al. (2012) for further exploration].

of primary productivity to myctophids and higher predators. Overall, very little is known of the ecology of small euphausiids in the Southern Ocean, although studies have shown that they can be numerically more abundant than krill in some regions (Daly and Macaulay, 1988). Given that these small euphausiids are a major dietary component of the Scotia Sea myctophid community, helping to sustain both their high biomass and role in the transfer of energy to higher predators, there is a pressing need for further ecological studies on Southern Ocean euphausiids, particularly their ecophysiological response to ocean-warming in the region.

\section{Higher Predator Perspective}

The SCAR Southern Ocean Diet and Energetics Database (Scientific Committee on Antarctic Research, 2018) lists 89 species of myctophid predator in 20 families of bird, fish, mammal and squid. For comparison, the database lists an additional 95 species of Antarctic krill predator in an additional 39 families, most of which are pelagic invertebrates. The predator family and species with the most diverse myctophid diets are the Procellariidae (fulmarine petrels and allies) and the Antarctic fur seal, Arctocephalus gazella, with 19 and 17 myctophid prey species, respectively. The most diverse family of myctophid predators ( 35 species) is the Myctophidae itself. Specialist mesopelagic foragers including king penguins, Aptenodytes patagonicus, maintain a consistently high proportion of myctophids in their diet (Olsson and North, 1997) while generalist predators such as fur seals, have more variable proportions and usually include krill as a significant diet component (Staniland et al., 2011). For many air-breathing predators, krill are more accessible than myctophids as the former are most concentrated in the surface layers $(<200 \mathrm{~m})$ of shelf and shelf break waters in the Scotia Sea (Atkinson et al., 2008), while foraging for myctophids generally requires deeper dives and longer trips from land. Evidence from South Georgia further suggests that fur seal population sizes are larger, with heavier females, in regions where both krill and myctophids are readily available compared to those in which myctophids are rare (Staniland et al., 2011). This suggests that the high energy content of myctophids is a valuable additional diet component, rather than an alternative to abundant krill.

Some estimates of myctophid consumption by predators are available from food web models. Sizeable between-model differences are particularly apparent in the Antarctic Peninsula and South Shetland Islands region where Suprenand and Ainsworth (2017) estimated that consumption of myctophids amounts to 0.22 tonnes $\mathrm{km}^{-2}$ year ${ }^{-1}$ whereas Cornejo-Donoso and Antezana (2008) estimated that consumption of E. antarctica alone is 19.18 tonnes $\mathrm{km}^{-2}$ year $^{-1}$. For the Scotia Sea, Hill et al. (2012) estimated that consumption of pelagic fish on the South Georgia Shelf was c. 4.04 tonnes $\mathrm{km}^{-2}$ year ${ }^{-1}$ compared to 58 tonnes $\mathrm{km}^{-2}$ year $^{-1}$ of Antarctic krill. These estimates show that myctophids are food for a diverse community of predators in the Scotia Sea and wider Southern Ocean, and that total consumption is substantial. However, the differences between estimates reflect significant uncertainty in the parameterization of these important but poorly studied food web components. 


\section{Conceptual Food Web Connections and Biomass Flows}

Murphy et al. (2007b) conceptually illustrated the transition between krill-based and alternative trophic pathways in parts of the Scotia Sea food web under scenarios of high and low annual (and regional) krill abundance, highlighting the important role of myctophids in this system (Figure 3). This conceptualization was refined to incorporate new perspectives on the role of small versus large myctophids and other key trophic connections revealed in our synthesis. However, the level of biomass flow through each trophic connection involving myctophids remains poorly understood, which confounds our understanding of the operation of the myctophid-based trophic pathway during different scenarios of krill abundance in the system. As a first attempt to address this issue, we compiled information from this synthesis together with published data generated from an exemplar food web model for the northern Scotia Sea (Hill et al., 2012) to construct illustrative estimates of relative biomass flow through the pelagic food web. The food web model (Hill et al., 2012) provides estimates of average trophic flows, in terms of biomass, for the South Georgia shelf based on summer data. This describes a high krill scenario and has some important limitations as a description of the whole Scotia Sea. Firstly, productivity on the South Georgia shelf is higher than that for many parts of the Scotia Sea (Atkinson et al., 2001). Secondly faunal community composition also varies throughout the Scotia Sea, particularly with latitude and seabed depth. We dealt with the first issue by expressing flows in relative terms, where a value of 1 represents krill consumption by large myctophids (which has an estimated median value of $16.8 \mathrm{Mt}$ year $^{-1}$ for the whole Scotia Sea). The second issue is partly resolved by the aggregation of many species into functional groups in the model, and by the fact that the model considers only local feeding rather than the total consumption by the high concentrations of land-based predators which breed on South Georgia. We modified the model flow estimates so that the diet composition of myctophids reflects the total consumption estimates in Table 6. We represented the low krill scenario by reducing flows from krill by $80 \%$, and all subsequent flows proportionately. This doubled the importance of myctophids in upper trophic level diets relative to that of krill, but nonetheless reduced the total prey consumption by these predators. We did not include any compensating increase in copepod production or diet switching by predators. These scenarios are explored further in Hill et al. (2012).

The trophic flow estimates in Figure 3 are preliminary. Nonetheless, some tentative conclusions can be drawn. The illustrated myctophid pathway supplies less than $10 \%$ of upper trophic level food requirements and even in our low krill scenario, the krill pathway still supplies six times more food than does the myctophid pathway. Indeed, we had to reduce flows from krill by $98 \%$ before the two pathways became equally important. Furthermore, large myctophids might supply considerably more food to upper trophic levels than do small myctophids. Assuming that consumption by upper trophic levels is proportional to the relative biomass of the two groups (estimated from Table 1), large myctophids account for 92 and
$78 \%$ of myctophid consumption by upper trophic levels in the high and low krill scenarios, respectively. As large myctophids feed on krill, the low krill scenario also impacts the myctophid pathway. These results suggest that while the myctophid pathway might help to buffer the effects of temporal and spatial variability in krill availability, current predator population levels could not persist in a long-term low krill scenario. Myctophid-focused food web models which cover the oceanic parts of the Scotia Sea will be necessary to refine these flow estimates. There are significant uncertainties over the annual production of zooplankton and krill as well as the structure of the food web in the winter months. Studies designed to constrain these uncertainties would aid development of food web models.

\section{Expatriation Implications for Food Web Stability}

Since the majority of the mostly non-krill consuming myctophids in the Scotia Sea appear to be non-reproducing migrants from waters north of the APF (Hulley, 1981; Leob et al., 1993; Saunders et al., 2017), the capacity of myctophids to maintain a stable krill-independent trophic pathway seems to be largely dependent upon inter-specific physiological and behavioral traits, environmental conditions and oceanographic transport mechanisms that govern the influx of a high biomass of expatriate myctophids to the region. Disruptions to oceanographic transport mechanisms (e.g., changes in circulation in frontal systems or associated with eddies) could potentially reduce the level of expatriates entering the Scotia Sea, leading to reductions in food web stability. Stability in this component of the food web also appears to be linked directly to ecological processes that control myctophid recruitment success, and hence their overall biomass, at lower latitudes where most populations reproduce. However, there is little information on the reproductive ecology of Southern Ocean myctophids (Oven et al., 1990). Myctophid expatriation effects are further likely to be associated with regional variations in food web stability, as migration capacity appears to be related to body size and temperature in the Scotia Sea myctophid community (Saunders and Tarling, 2018). For example, the smaller, expatriate myctophid species appear unable to penetrate the colder waters of the southernmost regions of the Scotia Sea, thus limiting their potential for buffering the predominantly krill-dominated system in such regions during sustained periods of low krill availability. These regions may therefore be more susceptible to reductions in food web stability than those in the northern Scotia Sea. Presently, there are clear knowledge gaps regarding the movement ecology of Southern Ocean myctophids, and new studies on transport pathways, behavioral mechanisms, remote oceanographic conditions and the role of immigration are imperative for assessing food web stability in the region (Hunt et al., 2016).

\section{Southern Ocean Context}

Although our assessment of food web interactions is appropriate for the Scotia Sea, there is still a need to examine the food web structure and the role of myctophids in other sectors of the Southern Ocean before they can be extrapolated. The Scotia Sea is an interesting case study because it is one of the most 
productive regions of the Southern Ocean and sustains some of highest abundances of krill (Marr, 1962; Atkinson et al., 2004; Holm-Hansen et al., 2004). It also sustains some of the most abundant higher predator populations in the Southern Ocean (Croxall et al., 1988). Furthermore, unlike most other sectors, the Scotia Sea is a region where krill extend as far north as the APF, whereas krill are predominately concentrated around the Antarctic continent in other sectors (Atkinson et al., 2008). Therefore, food web structure and trophodynamics are likely to be different in other regions of the Southern Ocean, particularly regarding the role of krill. Knowledge of the quantitative diet composition, trophodynamics and abundance of myctophids is largely lacking for most other sectors of the Southern Ocean. There are two key considerations in terms of food web operation in the region. Firstly, there are several sectors of the Southern Ocean where krill are relatively sparse, unlike the Scotia Sea which contains a large proportion of the Southern Ocean krill population (Atkinson et al., 2009). Therefore, it has been proposed that mesopelagic fish, including myctophids, are likely to be a more dominant trophic pathway in these regions than krill (Murphy et al., 2012). New studies in these regions will be insightful in understanding the broader scale role of myctophids in the food web and, in particular, how large krillconsuming myctophids fare when one of their main apparent food resources is less available. Secondly, many myctophid species appear to be expatriate migrants from regions further north, with behavioral processes and oceanographic transport mechanisms critical in maintaining their high abundance in regions south of the APF. However, the oceanographic transport mechanisms across the APF are unlikely to be uniform and productivity is spatially variable, meaning that myctophid prey in the Southern Ocean are likely to be distributed patchily (Hunt et al., 2016). As a consequence, the abundance and species composition of the migrant myctophid community is likely to be variable throughout the Southern Ocean, which may change the structure and dynamics of food webs at regional and subregional scales.

\section{Impact of Ocean-Warming on Food Web Dynamics}

The Scotia Sea - Antarctic Peninsula region has experienced rapid climate-related change over recent decades including increases in sea surface temperature (Meredith and King, 2005; Whitehouse et al., 2008) and reductions in sea ice extent (Stammerjohn et al., 2008; Turner et al., 2015). Climate models suggest that further warming and sea ice loss is likely during the current century (Hill et al., 2013; Cavanagh et al., 2017). Antarctic krill is a stenothermic species, but its distribution in this region extends north of $55^{\circ} \mathrm{S}$, where present temperatures are already close to its thermal limits for growth (Atkinson et al., 2008). Further warming is expected to make these habitats less favorable for krill (Hill et al., 2013; Murphy et al., 2017). The population dynamics of krill in this region have a complex relationship with sea ice (Murphy et al., 2007a,b), which is an important overwintering habitat for larval krill and hence for survival and recruitment (Meyer et al., 2017). These factors suggest that regional krill populations may be negatively affected by climate change (Flores et al., 2012).

There has been no large-scale monitoring of the regional krill population, but some areas where krill occur predictably have been monitored since the 1990s. This monitoring has detected high inter-annual variability, but no directional trends in indices of krill abundance or biomass (Fielding et al., 2014; Saba et al., 2014; Kinzey et al., 2015; Loeb and Santora, 2015). An integrated model analysis focused on the tip of the Antarctic Peninsula suggests that this pattern of high variability but no trend has persisted since the 1970s (Kinzey et al., 2018). Other studies, using net data from multiple sources, report significant declines in numerical density over the same period (Loeb et al., 1997; Atkinson et al., 2004), but no significant trend in data sourced solely from the more common large nets (mouth opening $>3 \mathrm{~m}^{2}$ ) (Atkinson et al., 2004; Cox et al., 2018). The most recent net data study, which examined spatial and temporal changes, found large scale, spatially coherent change in the krill stock, including southward contraction of its distribution, a strong decline in numerical density north of $60^{\circ} \mathrm{S}$ and a decline in recruitment which was linked to fluctuations in the Southern Annular Mode of climate variability (Atkinson et al., 2019).

Projection models suggest that habitat contraction (Hill et al., 2013), and reduced hatch success (Kawaguchi et al., 2013), recruitment (Murphy et al., 2007a; Piñones and Fedorov, 2016) and biomass (Klein et al., 2018; Tulloch et al., 2019) in Antarctic krill are all potential consequences of future climate change, with impacts likely to be most severe around South Georgia at the northern edge of the Scotia Sea (Constable et al., 2014). There are significant uncertainties associated with such projections, and other studies suggest that the krill stock could benefit from enhanced larval habitat and primary production (Melbourne-Thomas et al., 2016; Tulloch et al., 2018). Nonetheless, there is strong evidence to suggest that the overall lifecycle of Antarctic krill is vulnerable to the effects of climate change, and concern about the potential ecosystem consequences of climate driven changes in the krill stock (Flores et al., 2012; McBride et al., 2014; Morley et al., 2019). Given their role as major consumers of Antarctic krill and alternative prey for many of its vertebrate predators, there is a need to explore these consequences for myctophids and their predators. A plausible consequence is increased predation pressure on myctophids leading to substantial reductions in the abundance of all myctophid species in the region, adverse impacts on their population dynamics and changes in their behavior. Our study further highlights that populations of the larger, krill consuming myctophids, particularly E. antarctica, G. nicholsi, and $G$. braueri, may also be impacted concurrently by sustained reductions of krill in their diet. Although it is possible that such species could survive periods of krill shortages by increasing their intake of other prey taxa, particularly copepods and small euphausiids, these food sources are unlikely to yield the same calorific content as krill per unit effort of foraging (Schaafsma et al., 2018). These myctophids may therefore be unable to meet their metabolic demands as efficiently through such a dietary shift and, consequently, they could be subjected to starvation stresses and increased population depletion. 
Interestingly, Ward et al. (2018) reported a marked increase $(\sim 20-55 \%)$ in the abundance of large calanoid copepods in the Scotia Sea between the 1930s and recent years and hypothesized that this could be linked to a decrease in krill abundance in the region, which has resulted in more phytoplankton food availability to copepods and reduced predation pressure on them (Atkinson et al., 1999). Under a scenario of sustained oceanwarming and future reductions in krill abundance, it is therefore possible that other sources of secondary production may further increase in the Scotia Sea, providing greater concentrations of prey for myctophids. Additionally, primary productivity has also been predicted to increase in the region with warming surface waters, which is also likely to result in increased levels of some heterotrophs that could available to myctophids (Smith and Comiso, 2008; Proud et al., 2017). These effects may therefore be important in alleviating starvation stress for krill-consuming species in the Scotia Sea (Hill et al., 2012). Nonetheless, the relative specificity of myctophid diets in terms of prey taxa and size suggest that such changes in the prey field would impact the size and species composition of the myctophid community (Saunders et al., 2014, 2015b, 2018).

Myctophids are also likely to be impacted directly by sustained ocean-warming in the Scotia Sea, with changes in temperature altering their distribution patterns, abundance, life cycles and behavior, which could further affect food web stability in the region (Freer et al., 2019). For example, a recent study found that the Scotia Sea myctophid community adheres to Bergmann's rule, a size-temperature rule whereby species and individuals are larger in colder waters at higher latitudes (Saunders and Tarling, 2018). The capacity to attain a large body size appears to be an important attribute in the extent to which both myctophid species and life cycle stages of particular species can penetrate and reside in colder waters at higher latitudes. With increased ocean-warming across the Scotia Sea, it is therefore likely that smaller sized species and life stages will increase their southernmost ranges to waters at higher latitudes, although the latitudinal extent to this may be limited by bathymetry at the Antarctic continental slope and photoperiod (Kaartvedt, 2008). This could lead to smaller species displacing the larger species and life stages that occur in these higher latitude regions. The overall effect of such a shift in community structure would be a reduction in the size spectra of myctophids in the Scotia Sea, which may render them less suitable as prey for higher predators and reduce their capacity to support the ecosystem if krill also become less available. Sustained ocean-warming could also reduce myctophid abundance substantially due to disruptions of oceanographic transport mechanisms that are likely to be critical to the influx and movement of expatriate biomass across the region (Hunt et al., 2016). Consequently, myctophids would be less available to higher predators throughout the region, compromising food web stability under scenarios of sustained reductions in krill abundance. Environmentally induced changes to myctophid behavioral patterns, such as schooling and vertical migrations, may further contribute to this effect (Proud et al., 2017). For example, evidence from the Scotia Sea indicates that the vertical distribution patterns of some myctophid species, such as $K$. anderssoni, E. carlsbergi, and P. bolini, are determined by temperature (Kozlov et al., 1991; Collins et al., 2008; Saunders and Tarling, 2018). Thermal changes in water mass properties, particularly the temperature minima depth, may therefore change the vertical migration behavior of species that occupy specific thermal ranges in the water column.

Given the uncertainties of the impacts of broad-scale environmental change on the Scotia Sea myctophid community (Freer et al., 2017), it remains questionable how long, and to what extent, the myctophid-based trophic pathway can compensate for a reduction in krill and how ecosystem structure will alter as a consequence. However, there are several regions of the Southern Ocean with comparatively low Antarctic krill abundance that could potentially offer some insight into the structure of the Scotia Sea food web with less krill. Such regions include Heard Island, Kerguelen Island (Indian Ocean sector), and Macquarie Island (Pacific sector). Despite relatively low abundances of krill, these regions sustain an abundant and diverse myctophid community that appears central to the operation of the food web, suggesting that some myctophid populations have the capacity to prevail when krill is reduced in their prey field (Perissinotto and McQuaid, 1992; Gaskett et al., 2001; Flynn and Williams, 2012). However, these low-krill regions appear to sustain lower populations of higher predators, particularly fur seals and Macaroni penguins, compared to regions with high krill abundance, such as South Georgia (Cherel et al., 1997; Boyd, 2002a; Page et al., 2003; Robinson, 2003). Unlike at South Georgia, fur seals in these other regions have diets dominated by myctophids and they seldom consume Antarctic krill, whilst Macaroni penguins consume both small euphausiids and myctophids, as opposed to mostly krill (Cherel et al., 1997; Boyd, 2002a; Page et al., 2003; Robinson, 2003; Deagle et al., 2007). These findings therefore support the concept that alternative trophic pathways are not as efficient as the krill-based one and a shift toward such pathways under sustained oceanwarming is likely to result in a major decline in higher predator populations in the Scotia Sea over the longer term.

\section{Overview: Myctophid Pathways and Food Web Stability}

The above synthesis of information from across a series of specific studies undertaken during the last decade has highlighted the crucial role of myctophids in Scotia Sea food webs (Murphy et al., 2007b). A key aspect of that role that has not been previously emphasized, is that myctophids operate as both krill-dependent and krill-independent trophic pathways in this system. These alternative trophic pathways are principally determined by myctophid species size i.e., some large myctophid species eat krill and comprise a more krill-dependent trophic pathway, whilst the small species seldom eat krill and comprise a krill-independent pathway (Figure 3). These different pathways of energy flow will contribute to overall ecosystem stability and resilience.

It therefore follows that large krill-consuming myctophids are likely to be impacted directly by potential regional declines in krill abundance, whilst small non-krill-consuming species may be more resilient to such effects. Consequently, the importance of myctophids in maintaining food web stability may increase under 
such scenarios, primarily due to the trophic role of these smaller myctophid species (Figure 3). These larger krill-consuming myctophid species exhibit a degree of dietary flexibility that may enable populations to persist in the region under scenarios of krill decline, albeit at lower levels of abundance, by switching to other food sources, such as copepods and amphipods.

\section{KNOWLEDGE GAPS}

This review demonstrates that considerable progress has been made in assessing the importance of myctophids in Southern Ocean food webs, particularly in the Scotia Sea region. However, despite this progress, there remain substantial knowledge gaps that require further investigation. One of the most important uncertainties in the trophodynamics of myctophids result from the clear limitations in our estimates of species abundance and biomass, which are confounded primarily due to difficulties in sampling them appropriately with net and acoustic methodologies (Irigoien et al., 2014; Proud et al., 2018). Recent studies have highlighted that net sampling grossly underestimates the abundance and biomass of mesopelagic fish, so the overall calculations of the predator impact of myctophids on their prey could be underestimated (Irigoien et al., 2014). Zooplankton populations are also inherently variable in space and time and, as a consequence, net based measurements of the prey field may be underrepresented (Ward et al., 2012). Understanding of the oceanographic and behavioral mechanisms that govern the migration pathways of myctophids into the Scotia Sea, as well as the processes that impact their annual recruitment success in waters in more remote regions, are critical knowledge gaps and new studies are required as a priority for assessing food web resilience under scenarios of sustained ocean-warming and reductions in krill abundance. A further consideration is that conventional stomach sample analyses may not adequately reflect the long-term diets of myctophids, particularly regarding the role of soft-bodied organisms such as salps and gelatinous organisms, although the data available are consistent with observations from biochemical dietary studies that provide a more timeintegrated synopsis of mesopelagic fish diets (Cherel et al., 2010; Stowasser et al., 2012). The application of new advances in genetic identification techniques to fish stomach contents samples may provide valuable insight into the diet composition of Southern Ocean myctophids and food web structure, particularly in relation to soft-bodied organisms (Sheppard and Harwood, 2005; Clarke et al., 2018).

To date, the available trophic studies on myctophid fish have only been conducted during single years and there remain uncertainties regarding inter-annual variations in diet and trophodynamics in each season. There are currently no data available for the winter season in any region of the Southern Ocean. Clearly, continued sampling in different years would provide much greater insight into food web dynamics and the role of myctophid fish, although sampling myctophids and their prey at finer spatial and temporal scales is challenging in the Southern Ocean and large-scale data may prove to be the only window of observation in the short to medium term. There are also rare myctophid species that occur occasionally in the Scotia Sea community for which virtually nothing is known about their ecology or trophodynamics (Hulley, 1981). Much of the quantitative data to date are confined to the Scotia Sea, which presents a unique case study into the trophodynamics of myctophids, and there is clearly a requirement for studies in the other sectors of the Southern Ocean to put recent findings into a circumpolar context. Furthermore, calculations of the predatory impact of myctophids on their prey field incorporate several key assumptions based on limited data on temperature dependent digestion rates, meal sizes, and daily rations. For example, daily rations are based on limited observations and are only available for a few species in waters south of the APF. Some species, such as E. antarctica and $K$. anderssoni, exhibit night-time vertical distribution patterns that suggest foray-type vertical migration patterns (Collins et al., 2008; Saunders et al., 2014; Lourenço et al., 2017), raising the possibility that feeding patterns may not be daily across all components of their populations (Pepin, 2013). Calculations also remain unresolved for the different prey life stages, which is particularly problematic for larger species, such as Antarctic krill. Current estimates of krill biomass are limited to post-larval stages, which may not be the primary size range consumed by myctophids, particularly in regions around the sea ice zone where juvenile and larval krill predominate (Atkinson et al., 2009; Hill et al., 2016).

Although this synthesis develops the conceptual the role of myctophids in the operation of Southern Ocean food webs, it also demonstrates a requirement to explore and substantiate these suppositions more quantitatively through robust food web modeling (St John et al., 2016). Food web studies in the northern Scotia Sea have demonstrated the utility of using modeling frameworks such as Ecopath for investigating biomass flows and changes in food web dynamics under plausible scenarios of change in key trophic links (Hill et al., 2012). An extension of this approach that better accommodates factors such as the role of large versus small myctophids, diet switching by higher predators and the dynamics of other key trophic connections such as small euphausiids and amphipods, at more appropriate spatial scales will provide important insights into the operation of the Scotia Sea food web and its sensitivity to change. Finally, there remains a pressing requirement to monitor changes in primary production, ocean temperature and ocean acidification to examine the impacts of environmental change on the Scotia Sea myctophid community, as well as a need to develop robust ecosystem models that represent the dynamics of phytoplankton, zooplankton and mid-trophic levels, such as krill and myctophids.

\section{CONCLUDING REMARKS}

In this study, we provide new insights into the trophic role of myctophids in the Southern Ocean food web and update existing paradigms of the structure of this system. We highlight the complex and multifaceted way in which the myctophid community may respond to future change in Southern Ocean ecosystems. In particular, we demonstrate that myctophids link secondary productivity to higher predators through both 
krill-dependent and krill-independent trophic pathways and, consequently, that myctophids are likely to be impacted to some extent under realistic scenarios of long-term reductions in krill abundance, which will have implications for food web stability in the region. We also substantiate that, partly due to their relatively high abundance and broad-scale distribution patterns, large myctophids are likely to be the greatest predators of krill in the Scotia Sea ecosystem, consuming substantially more krill than all other fish, birds and mammals combined. As such, myctophids are a major influence on krill mortality and are likely to be affected by management decisions concerning krill catch limits and fishing locations. This implies a need for a more robust consideration of myctophids in the advice which supports these decisions, including in ecosystem assessments and strategic ecosystem models. How resilient myctophids are to reductions in krill abundance and long-term environmental change, both directly and indirectly, remains unclear and there is a pressing need for new data to determine the extent to which myctophids can support the Scotia Sea ecosystem under such scenarios. Given that many species appear to be migrants from temperate and sub-tropical regions, future ecological studies of myctophids must also focus on regions outside of Antarctic waters where the core reproducing populations reside. Understanding the behavioral and oceanographic processes that govern their influx into Antarctic waters will also be key for future studies examining

\section{REFERENCES}

Atkinson, A., Hill, S. L., Pakhomov, E. A., Siegel, V., Reiss, C. S., Loeb, V. J., et al. (2019). Krill (Euphausia superba) distribution contracts southward during rapid regional warming. Nat. Clim. Change 9, 142-147. doi: 10.1038/s41558-0180370-z

Atkinson, A., Siegel, V., Pakhomov, E. A., Jessopp, M. J., and Loeb, V. (2009). A re-appraisal of the total biomass and annual production of Antarctic krill. Deep Sea Res. Part I Oceanogr. Res. Pap. 56, 727-740. doi: 10.1016/j.dsr.2008.12.007

Atkinson, A., Siegel, V., Pakhomov, E. A., Rothery, P., Loeb, V., Ross, R. M., et al. (2008). Oceanic circumpolar habitats of Antarctic krill. Mar. Ecol. Progr. Ser. 362, 1-23. doi: 10.3354/meps07498

Atkinson, A., Siegel, V., and Rothery, P. (2004). Long-term decline in krill stock and increase in salps within the Southern Ocean. Nature 432, 100-103. doi: 10.1038/nature02996

Atkinson, A., Ward, P., Hill, A., Brierley, A. S., and Cripps, G. C. (1999). Krillcopepod interactions at South Georgia, Antarctica, II. Euphausia superba as a major control on copepod abundance. Mar. Ecol.Progr. Ser. 176, 63-79. doi: 10.3354/meps 176063

Atkinson, A., Whitehouse, M. J., Priddle, J., Cripps, G. C., Ward, P., and Brandon, M. (2001). South georgia, antarctica: a productive, cold water, pelagic ecosystem. Mar. Ecol. Progr. Ser. 216, 279-308. doi: 10.3354/meps21 6279

Ballerini, T., Hofmann, E. E., Ainley, D. G., Daly, K., Marrari, M., Ribic, C. A., et al. (2014). Productivity and linkages of the food web of the southern region of the western Antarctic Peninsula continental shelf. Progr. Oceanogr. 122, 10-29. doi: 10.1016/j.pocean.2013.11.007

Belchier, M., and Lawson, J. (2013). Analysis of temporal variability in abundance, diversity and growth rates within the coastal ichthyoplankton assembalge of South Georgia (sub-Antarctic). Polar Biol. 36, 969-983. doi: 10.1007/s00300013-1321-9

Boyd, I. L. (2002a). Estimating food consumption of marine predators: antarctic fur seals and macaroni penguins. J. Appl. Ecol. 39, 103-119. doi: 10.1046/j.13652664.2002.00697.x

Boyd, I. L. (2002b). “The krill eating crabeater seal," in Encylopedia of Mammals, ed. D. W. Macdonald, (New York, NY: Academic Press). the structure and resilience of Southern Ocean ecosystems to sustained environmental change. Furthermore, understanding the dynamics of the Southern Ocean myctophid community, which is a major component of the global mesopelagic fish community, will be insightful in determining how global food webs and biogeochemical cycles operate, as well as being a model system for the possible impacts of climate change on global pelagic ecosystems.

\section{AUTHOR CONTRIBUTIONS}

RS synthesized the published literature and wrote the manuscript with input from all authors. SH assisted with the synthesis of higher predator trophodynamics data, conceptual food web biomass flows, and krill biomass estimates. GT and EM assisted with the concept design.

\section{FUNDING}

This work was carried out as part of the British Antarctic Survey's POETS and SCOOBIES Projects within the Ecosystems Programme, funded by the Natural Environment Research Council, which is a part of UK Research and Innovation.

Brown, C. R., and Klages, N. T. (1987). Seasonal and annual variation in the diets of macaroni (Eudyptes chrysolophus) and southern rockhopper (E. chrysocome) penguins at sub-Antarctic Marion Island. J. Zool. 212, 7-28. doi: 10.1111/j. 1469-7998.1987.tb05111.x

Cavanagh, R. D., Murphy, E. J., Bracegirdle, T. J., Turner, J., Knowland, C. A., Corney, S. P., et al. (2017). A synergistic approach for evaluating climate model output for ecological applications. Front. Mar. Sci. 4:308. doi: 10.3389/fmars. 2017.00308

Cherel, Y., Bocher, P., Trouve, C., and Weimerskirch, H. (2002). Diet and feeding ecology of blue petrels Halobaena caerulea at Iles Kerguelen, Southern Indian Ocean. Mar. Ecol. Progr. Ser. 228, 283-299. doi: 10.3354/meps228283

Cherel, Y., Fontaine, C., Richard, P., and Labat, J.-P. (2010). Isotopic niches and trophic levels of myctophid fishes and their predators in the Southern Ocean. Limnol. Oceanogr. 55, 324-332. doi: 10.4319/lo.2010.55.1.0324

Cherel, Y., Guinet, C., and Tremblay, Y. (1997). Fish prey of Antarctic fur seals Arctocephalus gazella at Ile de Croy, Kerguelen. Polar Biol. 17, 87-90. doi: 10.1007/s003000050109

Clarke, L. J., Trebilco, R., Walters, A., and Polanowski, A. M. (2018). DNAbased diet analysis of mesopelagic fish from the southern Kerguelen Axis. Deep Sea Res. Part II Top. Stud. Oceanogr. 2, 1-23. doi: 10.1016/j.dsr2.2018. 09.001

Collins, M. A., Ross, K. A., Belchier, M., and Reid, K. (2007). Distribution and diet of juvenile Patagonian toothfish on the South Georgia and Shag Rocks Shelves (Southern Ocean). Mar. Biol. 152, 135-147. doi: 10.1007/s00227-007-0667-663

Collins, M. A., Stowasser, G., Fielding, S., Shreeve, R., Xavier, J. C., Venables, H. J., et al. (2012). Latitudinal and bathymetric patterns in the distribution and abundance of mesopelagic fish in the Scotia Sea. Deep Sea Res. Part II Top. Stud. Oceanogr. 59-60, 189-198. doi: 10.1016/j.dsr2.2011.07.003

Collins, M. A., Xavier, J. C., Johnston, N. M., North, A. W., Enderlein, P., Tarling, G. A., et al. (2008). Patterns in the distribution of myctophid fish in the northern Scotia Sea ecosystem. Polar Biol. 31, 837-851. doi: 10.1007/s00300-0080423-422

Connan, M., Cherel, Y., and Mayzaud, P. (2007). Lipids from stomach oil of procellariiform seabirds document the importance of myctophid fish in the Southern Ocean. Limnol. Oceanogr. 52, 2445-2455. doi: 10.4319/lo.2007.52.6. 2445 
Constable, A. J., De La Mare, W., Agnew, D. J., Everson, I., and Miller, D. (2000). Managing fisheries to conserve the Antarctic marine ecosystem: practical implementation of the convention on the conservation of Antarctic marine living resources (CCMALR). ICES J. Mar. Sci. 57, 778-791. doi: 10.1006/jmsc. 2000.0725

Constable, A. J., Melbourne-Thomas, J., Corney, S. P., Arrigo, K. R., Barbraud, C., Barnes, D. K. A., et al. (2014). Climate change and Southern Ocean ecosystems I: how changes in physical habitats directly affect marine biota. Glob. Change Biol. 20, 3004-3025. doi: 10.1111/gcb.12623

Cornejo-Donoso, J., and Antezana, T. (2008). Preliminary trophic model of the antarctic peninsula ecosystem (Sub-area CCAMLR 48.1). Ecol. Model. 218, 1-17. doi: 10.1016/j.ecolmodel.2008.06.011

Cox, M. J., Candy, S., de la Mare, W. K., Gales, N., Nicol, S., and Kawaguchi, S. (2018). No evidence for a decline in the density of Antarctic krill Euphausia superba Dana, 1850, in the Southwest Atlantic sector between 1976 and 2016. J. Crustacean Biol. 38, 656-661. doi: 10.1093/jcbiol/ruy072

Croxall, J. P., McCann, T. S., Prince, P. A., and Rothery, P. (1988). "Reproductive performance of seabirds and seals at South Georgia and Signy Island, South Orkney Islands, 1976-1987: implications for Southern Ocean monitoring studies," in Antarctic Ocean and Resources Variability, ed. D. Sahrhage, (Berlin: Springer-Verlag).

Croxall, J. P., Reid, K., and Prince, P. A. (1999). Diet, provisioning and productivity responses of marine predators to differences in availability of Antarctic krill. Mar. Ecol. Progr. Ser. 177, 115-131. doi: 10.3354/meps 177115

Curran, M. A. J., van Ommen, T. D., Morgan, V. I., Phillips, K. L., and Palmer, A. S. (2003). Ice core evidence for sea ice decline since the 1950s. Science 302, 1203-1206. doi: 10.1126/science. 1087888

Daly, K. L., and Macaulay, M. C. (1988). Abundance and distribution of krill in the ice edge zone of the Weddell Sea, austral spring 1983. DeepSea Res. Part A Oceanogr. Res. Pap. 35, 21-41. doi: 10.1016/0198-0149(88)90055-90056

de la Mare, W. K. (1997). Abrupt mid-twentieth-century decline in Antarctic sea ice extent from whaling records. Nature 389, 387-400.

Deagle, B. E., Gales, N. J., Evans, K., Jarman, S. N., Robinson, S., Trebilco, R., et al. (2007). Studying seabird diet through genetic analysis of faeces: a case study on Macaroni Penguins (Eudyptes chrysolophus). PLoS One 2:e831. doi: 10.1371/journal.pone.0000831

Dickson, J., Morley, S. A., and Mulvey, T. (2004). New data on Martialia hyadesi feeding in the Scotia Sea during winter; with emphasis on seasonal and annual variability. J. Mar. Biol. Assoc. 84, 785-788. doi: 10.1017/S0025315404009944h

Donnelly, J., and Torres, J. J. (2008). Pelagic fishes in the Marguerite Bay region of the West Antarctic Peninsula continental shelf. Deep Sea Res. Part II Top. Stud. Oceanogr. 55, 523-539. doi: 10.1016/j.dsr2.2007.11.015

Ducklow, H. W., Baker, K., Martinson, D. G., Quetin, L. B., Ross, R. M., Smith, R. C., et al. (2007). Marine pelagic ecosystems: the West Antarctic Peninsula. Philos. Trans. R. Soc. B Biol. Sci. 362, 67-94. doi: 10.1098/rstb.2006.1955

Duhamel, G., Koubbi, P., and Ravier, C. (2000). Day and night mesopelagic fish assemblages off the Kerguelen Islands (Southern Ocean). Polar Biol. 23, 106-112. doi: 10.1007/s003000050015

Efremenko, V. N. (1986). Distribution of eggs and larvae of Myctophidae in the southern Atlantic. J. Ichthyol. 26, 141-147.

Everson, I. (1977). The Living Resources of the Southern Ocean. Rome: FAO.

Everson, I., Agnew, D. J., and Miller, D. G. M. (2000). "Krill fisheries and the future," in Krill: Biology, Ecology and Fisheries, ed. I. Everson, (Oxford: Blackwell Science), 345-348. doi: 10.1002/9780470999493.ch14

Everson, I., Parkes, G., Kock, K. H., and Boyd, I. L. (1999). Variation in standing stock of the mackerel icefish Champsocephalus gunnari at South Georgia. J. Appl. Ecol. 36, 591-603. doi: 10.1046/j.1365-2664.1999.00425.x

Fielding, S., Watkins, J. L., Collins, M. A., Enderlein, P., and Venables, H. J. (2012). Acoustic determination of the distribution of fish and krill across the Scotia Sea in spring 2006, summer 2008 and autumn 2009. Deep Sea Res. Part II Top. Stud. Oceanogr. 59, 173-188. doi: 10.1016/j.dsr2.2011.08.002

Fielding, S., Watkins, J. L., Trathan, P. N., Enderlein, P., Waluda, C. M., Stowasser, G., et al. (2014). Interannual variability in Antarctic krill (Euphausia superba) density at South Georgia, Southern Ocean: 1997-2013. ICES J. Mar. Sci. 71, 2578-2588. doi: 10.1093/icesjms/fsu104

Flores, H., Atkinson, A., Kawaguchi, S., Krafft, B. A., Milinevsky, G., Nicol, S., et al. (2012). Impact of climate change on Antarctic krill. Mar. Ecol. Progr. Ser. 458, 1-19. doi: 10.3354/meps09831

Flores, H., de Putte, A. P. V., Siegel, V., Pakhomov, E. A., Van Franeker, J. A., Meesters, H. W. G., et al. (2008). Distribution, abundance and ecological relevance of pelagic fishes in the Lazarev Sea, Southern Ocean. Mar. Ecol. Progr. Ser. 367, 271-282. doi: 10.3354/meps07530

Flynn, A. J., and Williams, A. (2012). Lanternfish (Pisces: Myctophidae) biomass distribution and oceanographic-topographic associations at Macquarie Island, Southern Ocean. Mar. Freshw. Res. 63, 251-263. doi: 10.1071/ mf11163

Forcada, J., Trathan, P. N., Boveng, P. L., Boyd, I. L., Burns, J. M., Costa, D. P., et al. (2012). Responses of Antarctic pack-ice seals to environmental change and increasing krill fishing. Biol. Conserv. 149, 40-50. doi: 10.1016/j.biocon. 2012.02.002

Freer, J. J., Partridge, J. C., Tarling, G. A., Collins, M. A., and Genner, M. J. (2017). Predicting ecological responses in a changing ocean: the effects of future climate uncertainty. Mar. Biol. 165:7. doi: 10.1007/s00227-017-3239-3231

Freer, J. J., Tarling, G. A., Collins, M. A., Partridge, J. C., and Genner, M. J. (2019). Predicting future distributions of lanternfish, a significant ecological resource within the Southern Ocean. Divers. Distrib. 25, 1259-1272. doi: 10.1111/ddi. 12934

Gaskett, A. C., Bulman, C., He, X., and Goldsworthy, S. D. (2001). Diet composition and guild structure of mesopelagic and bathypelagic fishes near Macquarie Island, Australia. N. Zeal. J. Mar. Freshw. Res. 35, 469-476. doi: 10.1080/ 00288330.2001 .9517016

Gerasimova, O. V. (1990). Feeding and food intake of Electrona carlsbergi (Taning, 1932) Myctophidae. CCAMLR Sel. Sci. Pap. 7, 411-416.

Gjøsaeter, J., and Kawaguchi, K. (1980). A Review of the World Resources of Mesopelagic Fish, Vol. 193. Rome: Food and Agriculture Organization, 1-151.

Greely, T. M., Gartner, J. V., and Torres, J. J. (1999). Age and growth of Electrona antarctica (Pisces: Myctophidae), the dominant mesopelagic fish of the Southern Ocean. Mar. Biol. 133, 145-158. doi: 10.1007/s002270050453

Hill, S. L., Atkinson, A., Darby, C., Fielding, S., Krafft, B. A., Godo, O. R., et al. (2016). Is current management of the Antarctic krill fishery in the Atlantic sector of the Southern Ocean precautionary? CCAMLR Sci. 23, 31-51.

Hill, S. L., Keeble, K., Atkinson, A., and Murphy, E. J. (2012). A foodweb model to explore uncertainties in the South Georgia shelf pelagic ecosystem. Deep Sea Res. Part II Top. Stud. Oceanogr. 59-60, 237-252. doi: 10.1016/j.dsr2.2011.09.001

Hill, S. L., Phillips, T., and Atkinson, A. (2013). Potential climate change effects on the habitat of Antarctic krill in the Weddell quadrant of the Southern Ocean. PLoS One 8:e72246. doi: 10.1371/journal.pone.0072246

Hill, S. L., Reid, K., Thorpe, S. E., Hinke, J., and Watters, G. M. (2007). A compilation of parameters for ecosystem dynamics models of the Scotia SeaAntarctic Peninsula region. CCAMLR Sci. 14, 1-25.

Hofmann, E. E., Klinck, J. M., Locarnini, R. A., Fach, B. A., and Murphy, E. J. (1998). Krill transport in the Scotia Sea and environs. Antarct. Sci. 10, 406-415. doi: 10.1017/s0954102098000492

Holm-Hansen, O., Kahru, M., Hewes, C. D., Kawaguchi, S., Kameda, T., Sushin, V. A., et al. (2004). Temporal and spatial distribution of chlorophyll-a in surface waters of the Scotia Sea as determined by both shipboard measurements and satellite data. Deep Sea Res. Part II Top. Stud. Oceanogr. 51, 1323-1331. doi: 10.1016/j.dsr2.2004.06.004

Hopkins, T. L., and Torres, J. J. (1989). Midwater food web in the vicinity of a marginal ice zone in the western Weddell Sea. Deep Sea Res. 36, 543-560. doi: 10.1016/0198-0149(89)90005-8

Hulley, P. A. (1981). Results of the research cruises of FRV "Walther Herwig" to South America. 58. Family Myctophidae (Osteichthyes, Myctophiformes). Arch. fur Fischereiwissenschaft 31, 1-300.

Hulley, P. A. (1990). "Myctophidae," in Fishes of the Southern Ocean, eds O. Gon, and P. C. Heemstra, (Grahamstown: J.L.B. Smith Institute of Ichthyology), $146-178$.

Hunt, G. L., Drinkwater, K. F., Arrigo, K., Berge, J., Daly, K. L., Danielson, S., et al. (2016). Advection in polar and sub-polar environments: impacts on high latitude marine ecosystems. Progr. Oceanogr. 149, 40-81. doi: 10.1016/j.pocean. 2016.10.004

Irigoien, X., Klevjer, T. A., Rostad, A., Martinez, U., Boyra, G., Acuna, J. L., et al. (2014). Large mesopelagic fishes biomass and trophic efficiency in the open ocean. Nat. Commun. 5:3271. doi: 10.1038/ncomms4271

Kaartvedt, S. (2008). Photoperiod may constrain the effect of global warming in arctic marine systems. J. Plankton Res. 30, 1203-1206. doi: 10.1093/plankt/ fbn 075

Kawaguchi, S., Ishida, A., King, R., Raymond, B., Waller, N., Constable, A., et al. (2013). Risk maps for Antarctic krill under projected Southern 
Ocean acidification. Nat. Clim. Change 3:843. doi: 10.1038/nclimate 1937

Kinzey, D., Watters, G. M., and Reiss, C. S. (2015). Selectivity and two biomass measures in an age-based assessment of Antarctic krill (Euphausia superba). Fish. Res. 168, 72-84. doi: 10.1016/j.fishres.2015.03.023

Kinzey, D., Watters, G. M., and Reiss, C. S. (2018). Estimating recruitment variability and productivity in Antarctic krill. Fish. Res. 217, 98-107. doi: 10. 1016/j.fishres.2018.09.027

Klein, E. S., Hill, S. L., Hinke, J. T., Phillips, T., and Watters, G. M. (2018). Impacts of rising sea temperature on krill increase risks for predators in the Scotia Sea. PLoS One 13:e0191011. doi: 10.1371/journal.pone.0191011

Kock, K. H., Barrera-Oro, E., Belchier, M., Collins, M. A., Duhamel, G., Hanchet, S., et al. (2012). The role of fish as predators of krill (Euphausia superba) and other pelagic resources in the Southern Ocean. CCAMLR Sci. 19, 115-169.

Kock, K. H., Wilhelms, S., Everson, I., and Groger, J. (1994). Variations in the diet composition and feeding intensity of mackerel icefish Champsocephalus gunnarii at South Georgia (Antarctic). Mar. Ecol. Progr. Ser. 108, 43-57. doi: 10.3354/meps 108043

Koubbi, P., Duhamel, G., and Hebert, C. (2001). Seasonal relative abundance of fish larvae inshore at Iles Kerguelen, Southern Ocean. Antarct. Sci. 13, 385-392. doi: 10.1017/s0954102001000542

Kozlov, A. N., Shust, K., and Zemsky, A. V. (1991). Seasonal and inter-annual variability in the distribution of Electrona carlsbergi in the Southern Polar Front area (the area to the north of South Georgia is used an example). CCAMLR Sel. Sci. Pap. 7, 337-368.

Kozlov, A. N., and Tarverdiyeva, M. I. (1989). Feeding of different species of Myctophidae in different parts of the Southern Ocean. J. Ichthyol. 29, $160-167$.

Lancraft, T. M., Torres, J. J., and Hopkins, T. L. (1989). Micronekton and macrozooplankton in the open waters near Antarctic Ice Edge Zones (AMERIEZ). Polar Biol. 9, 225-233. doi: 10.1007/bf00263770

Laws, R. M. (1984). Antarctic Ecology. London: Academic Press.

Leob, V. J., Kellermann, A. K., Koubbi, P., North, A. W., and White, M. G. (1993). Antarctic larval fish assemblages: a review. Bull. Mar. Sci. 53, 416-449.

Linkowski, T. B. (1985). Population biology of the myctophid fish Gymnoscopelus nicholsi (Gillber, 1911) from the western South Atlantic. J. Fish Biol. 27, 683-698. doi: 10.1111/j.1095-8649.1985.tb03213.x

Loeb, V., Siegel, V., Holm-Hansen, O., Hewitt, R., Fraser, W., Trivelpiece, W., et al. (1997). Effects of sea-ice extent and krill or salp dominance on the Antarctic food web. Nature 387, 897-900. doi: 10.1038/43174

Loeb, V. J., and Santora, J. A. (2015). Climate variability and spatiotemporal dynamics of five Southern Ocean krill species. Progr. Oceanogr. 134, 93-122. doi: 10.1016/j.pocean.2015.01.002

Lourenço, S., Saunders, R. A., Collins, M. A., Shreeve, R. S., Assis, C. A., Belchier, M., et al. (2017). Life cycle, distribution and trophodynamics of the lanternfish Krefftichthys anderssoni (Lönnberg, 1905) in the Scotia Sea. Polar Biol. 40, 1229-1245. doi: 10.1007/s00300-016-2046-2043

Lubimova, T., Shust, K., and Popkov, V. (1987). Specific Features in the Ecology of Southern Ocean Mesopelagic Fish of the Family Myctophidae. Moscow: Nauka Press.

Marr, J. W. S. (1962). The natural history and geography of the Antarctic krill (Euphausia superba Dana). Discov. Rep. 32, 33-464.

McBride, M. M., Dalpadado, P., Drinkwater, K. F., Godø, O. R., Hobday, A. J., Hollowed, A. B., et al. (2014). Krill, climate, and contrasting future scenarios for Arctic and Antarctic fisheries. ICES J. Mar. Sci. 71, 1934-1955. doi: 10.1093/ icesjms/fsu002

Melbourne-Thomas, J., Corney, S. P., Trebilco, R., Meiners, K. M., Stevens, R. P., Kawaguchi, S., et al. (2016). Under ice habitats for Antarctic krill larvae: could less mean more under climate warming? Geophys. Res. Lett. 43, 10322-10327. doi: $10.1002 / 2016$ gl070846

Meredith, M. P., and King, J. C. (2005). Rapid climate change in the ocean west of the Antarctic Peninsula during the second half of the 20th century. Geophys. Res. Lett. 32:L19604. doi: 10.1029/2005gl024042

Meyer, B., Freier, U., Grimm, V., Groeneveld, J., Hunt, B. P. V., Kerwath, S., et al. (2017). The winter pack-ice zone provides a sheltered but food-poor habitat for larval Antarctic krill. Nat. Ecol. Evol. 1, 1853-1861. doi: 10.1038/s41559-0170368-363
Morley, S. A., Barnes, D. K. A., and Dunn, M. J. (2019). Predicting which species succeed in climate-forced polar seas. Front. Mar. Sci. 5:507. doi: 10.3389/fmars. 2018.00507

Moteki, M., Fujii, K., Amakasu, K., Shimada, K., Tanimura, A., and Odate, T. (2017). Distributions of larval and juvenile/adult stages of the Antarctic myctophid fish, Electrona antarctica, off Wilkes Land in East Antarctica. Polar Sci. 12, 99-108. doi: 10.1016/j.polar.2017.02.004

Murphy, E. J., Cavanagh, R. D., Hofmann, E. E., Hill, S. L., Constable, A. J., Costa, D. P., et al. (2012). Developing integrated models of Southern Ocean food webs: including ecological complexity, accounting for uncertainty and the importance of scale. Progr. Oceanogr. 102, 74-92. doi: 10.1016/j.pocean.2012.03.006

Murphy, E. J., Hofmann, E. E., Watkins, J. L., Johnston, N. M., Pinones, A., Ballerini, T., et al. (2013). Comparison of the structure and function of Southern Ocean regional ecosystems: the antarctic peninsula and South Georgia. J. Mar. Syst. 109, 22-42. doi: 10.1016/j.jmarsys.2012.03.011

Murphy, E. J., Thorpe, S. E., Tarling, G. A., Watkins, J. L., Fielding, S., and Underwood, P. (2017). Restricted regions of enhanced growth of Antarctic krill in the circumpolar Southern Ocean. Sci. Rep. 7:6963. doi: 10.1038/s41598-01707205-7209

Murphy, E. J., Trathan, P. N., Watkins, J. L., Reid, K., Meredith, M. P., Forcada, J., et al. (2007a). Climatically driven fluctuations in Southern Ocean ecosystems. Proc. R. Soc. B Biol. Sci. 274, 3057-3067. doi: 10.1098/rspb.2007.1180

Murphy, E. J., Watkins, J. L., Trathan, P. N., Reid, K., Meredith, M. P., Thorpe, S. E., et al. (2007b). Spatial and temporal operation of the Scotia Sea ecosystem: a review of large-scale links in a krill centred food web. Philos. Trans. R. Soc. B Biol. Sci. 362, 113-148. doi: 10.1098/rstb.2006.1957

Naumov, A. G. (1985). "System analysis of the structure of the Antarctic waters community," in Biological Basis of the Commercial Utilization of the Open Regions of the Ocean, eds M. E. Vinogradov, and M. V. Flint, (Moscow: Nauka Press), 57-80.

Olsson, O., and North, A. W. (1997). Diet of the King Penguin Aptenodytes patagonicus during three summers at South Georgia. Ibis 139, 504-512. doi: 10.1111/j.1474-919x.1997.tb04666.x

Oven, L. S., Konstantinova, M. P., and Shevchenko, N. F. (1990). Aspects of of reproduction and feeding of myctophids (Myctophidae) in the southwest Atlantic. J. Ichthyol. 30, 115-127.

Page, B., Welling, A., Chambellant, M., Goldsworthy, S. D., Dorr, T., and van Veen, R. (2003). Population status and breeding season chronology of Heard Island fur seals. Polar Biol. 26, 219-224.

Pakhomov, E. A., Perissinotto, R., and McQuaid, C. D. (1996). Prey composition and daily rations of myctophid fishes in the Southern Ocean. Mar. Ecol. Progr. Ser. 134, 1-14. doi: 10.3354/meps134001

Pepin, P. (2013). Distribution and feeding of Benthosema glaciale in the western Labrador Sea: fish-zooplankton interaction and the consequence to calanoid copepod populations. Deep Sea Res. Part I Oceanogr. Res. Pap. 75, 119-134. doi: 10.1016/j.dsr.2013.01.012

Perissinotto, R., and McQuaid, C. D. (1992). Land-based predator impact on vertically migrating zooplankton and micronekton advected to a Southern Ocean archipelago. Mar. Ecol. Progr. Ser. 80, 15-27. doi: 10.3354/meps080015

Phleger, C. F., Nelson, M. M., Mooney, B. D., and Nichols, P. D. (1999). Wax esters versus triacylglycerols in myctophid fishes from the Southern Ocean. Antarct. Sci. 11, 436-444. doi: 10.1017/s0954102099000565

Piatkowski, U., Rodhouse, P. G., White, M. G., Bone, D. G., and Symon, C. (1994). Nekton community of the Scotia Sea as sampled by the RMT 25 during austral summer. Mar. Ecol. Progr. Ser. 112, 13-28. doi: 10.3354/meps112013

Pichegru, L., Ropert-Coudert, Y., Kato, A., Takahashi, A., Dyer, B. M., and Ryan, P. G. (2011). Diving patterns of female macaroni penguins breeding on Marion Island, South Africa. Polar Biol. 34, 945-954. doi: 10.1007/s00300-0100950-955

Piñones, A., and Fedorov, A. V. (2016). Projected changes of Antarctic krill habitat by the end of the 21st century. Geophys. Res. Lett. 43, 8580-8589. doi: 10.1002/ 2016 gl069656

Proud, R., Cox, M. J., and Brierley, A. S. (2017). Biogeography of the global ocean's mesopelagic zone. Curr. Biol. 27, 113-119. doi: 10.1016/j.cub.2016.11.003

Proud, R., Handegard, N. O., Kloser, R. J., Cox, M. J., and Brierley, A. S. (2018). From siphonophores to deep scattering layers: uncertainty ranges for the estimation of global mesopelagic fish biomass. ICES J. Mar. Sci. 77, 718-733. doi: 10.1093/icesjms/fsy037 
Pusch, C., Hulley, P. A., and Kock, K. H. (2004). Community structure and feeding ecology of mesopelagic fishes in the slope waters of King George Island (South Shetland Islands, Antarctica). Deep Sea Res. Part IOceanogr. Res. Pap. 51, 1685-1708. doi: 10.1016/j.dsr.2004.06.008

Reid, K., Davis, D., and Staniland, I. J. (2006). Spatial and temporal variability in the fish diet of Antarctic fur seal (Arctocephalus gazella) in the Atlantic sector of the Southern Ocean. Can. J. Zool. 84, 1025-1037. doi: 10.1139/z06-071

Robinson, S. A. (2003). The foraging ecology of two sympatric fur seal species, Arctocephalus gazella and Arctocephalus tropicalis, at Macquarie Island during the austral summer. Mar. Freshw. Res. 53, 1071-1082.

Robison, B. H. (2003). What drives the diel vertical migrations of Antarctic midwater fish. J. Mar. Biol. Assoc. 83, 639-642. doi: $10.1017 / \mathrm{s} 0025315403007586 \mathrm{~h}$

Rowedder, U. (1979a). Feeding ecology of the myctophid Electrona antarctica (Gunther, 1878) (Teleostei). Meeresforschung 27, 252-263.

Rowedder, U. (1979b). Some aspects of the biology of Electrona antarctica (Gunther, 1878) (Family Myctophidae). Meeresforschung 27, 244-251.

Ruck, K. E., Steinberg, D. K., and Canuel, E. A. (2014). Regional differences in quality of krill and fish as prey along the Western Antarctic Peninsula. Mar. Ecol. Progr. Ser. 509, 39-55. doi: 10.3354/meps 10868

Saba, G. K., Fraser, W. R., Saba, V. S., Iannuzzi, R. A., Coleman, K. E., Doney, S. C., et al. (2014). Winter and spring controls on the summer food web of the coastal West Antarctic Peninsula. Nat. Commun. 5:4218. doi: 10.1038/ncomms5318

Saunders, R. A., Collins, M. A., Foster, E., Shreeve, R. S., Stowasser, G., Ward, P., et al. (2014). The trophodynamics of Southern Ocean Electrona (Myctophidae) in the Scotia Sea. Polar Biol. 37, 789-807. doi: 10.1007/s00300-014-1480-1483

Saunders, R. A., Collins, M. A., Shreeve, R., Ward, P., Stowasser, G., Hill, S. L., et al. (2018). Seasonal variation in the predatory impact of myctophids on zooplankton in the Scotia Sea (Southern Ocean). Progr. Oceanogr. 168, 123-144. doi: 10.1016/j.pocean.2018.09.017

Saunders, R. A., Collins, M. A., Stowasser, G., and Tarling, G. A. (2017). Southern Ocean mesopelagic fish communities in the Scotia Sea are sustained by mass immigration. Mar. Ecol. Progr. Ser. 569, 173-185. doi: 10.3354/meps12093

Saunders, R. A., Collins, M. A., Ward, A. J. W., Stowasser, G., Hill, S. L., Shreeve, R. S., et al. (2015a). Predatory impact of the myctophid fish community in the Scotia Sea (Southern Ocean). Mar. Ecol. Progr. Ser. 541, 45-64. doi: 10.3354/ meps11527

Saunders, R. A., Collins, M. A., Ward, P., Stowasser, G., Shreeve, R. S., and Tarling, G. A. (2015b). Distribution, population structure and trophodynamics of Southern Ocean Gymnoscopelus (Myctophidae) in the Scotia Sea. Polar Biol. 38, 287-308. doi: 10.1007/s00300-014-1584-1589

Saunders, R. A., Collins, M. A., Ward, P., Stowasser, G., Shreeve, R. S., and Tarling, G. A. (2015c). Trophodynamics of Protomyctophum (Myctophidae) in the Scotia Sea (Southern Ocean). J. Fish Biol. 87, 1031-1058. doi: 10.1111/jfb.12776

Saunders, R. A., Fielding, S., Thorpe, S. E., and Tarling, G. A. (2013). School characteristics of mesopelagic fish at South Georgia. Deep Sea Res. Part I Oceanogr. Res. Pap. 81, 62-77. doi: 10.1016/j.dsr.2013.07.007

Saunders, R. A., and Tarling, G. A. (2018). Southern Ocean mesopelagic fish comply with Bergmann's rule. Am. Nat. 191, 343-351. doi: 10.1086/695767

Schaafsma, F. L., Cherel, Y., Flores, H., van Franeker, J. A., Lea, M. A., Raymond, B., et al. (2018). Review: the energetic value of zooplankton and nekton species of the Southern Ocean. Mar. Biol. 165:129. doi: 10.1007/s00227-018-3386-z

Scheffer, A., Bost, C. A., and Trathan, P. N. (2012). Frontal zones, temperature gradient and depth characterize the foraging habitat of king penguins at South Georgia. Mar. Ecol. Progr. Ser. 465, 281-297. doi: 10.3354/meps09884

Schoener, T. W. (1974). Resource partitioning in ecological communites. Science 185, 27-39. doi: 10.1126/science.185.4145.27

Scientific Committee on Antarctic Research (2018). SCAR Southern Ocean Diet and Energetics Database. Kingston, TAS: Australian Antarctic Data Centre. doi: $10.26179 / 5 \mathrm{ba33} 96 \mathrm{f} 46 \mathrm{e} 42$

Sheppard, S. K., and Harwood, J. D. (2005). Advances in molecular ecology: tracking trophic links through predator-prey food-webs. Funct. Ecol. 19, 751762. doi: 10.1111/j.1365-2435.2005.01041.x

Shreeve, R. S., Collins, M. A., Tarling, G. A., Main, C. E., Ward, P., and Johnston, N. M. (2009). Feeding ecology of myctophid fishes in the northern Scotia Sea. Mar. Ecol. Progr. Ser. 386, 221-236. doi: 10.3354/meps08064

Smith, A. D. M. (2011). Impacts of fishing low-trophic level species on marine ecosystems. Science 333, 1147-1150. doi: 10.1126/science. 1209395

Smith, W. O. Jr., and Comiso, J. C. (2008). Influence of sea ice on primary production in the Southern Ocean: a satellite perspective. J. Geophys. Res. Oceans 113:C05S93. doi: 10.1029/2007JC0 04251

Smith, W. O., Ainley, D. G., and Cattaneo-Vietti, R. (2007). Trophic interactions within the Ross Sea continental shelf ecosystem. Philos. Trans. R. Soc. B Biol. Sci. 362, 95-111. doi: 10.1098/rstb.2006.1956

St John, M. A., Borja, A., Chust, G., Heath, M., Grigorov, I., Mariani, P., et al. (2016). A dark hole in our understanding of marine ecosystems and their services: perspectives from the mesopelagic community. Front. Mar. Sci. 3:31. doi: $10.3389 /$ fmars.2016.00031

Stammerjohn, S. E., Martinson, D. G., Smith, R. C., Yuan, X., and Rind, D. (2008). Trends in Antarctic annual sea ice retreat and advance and their relation to El Niño-Southern Oscillation and Southern Annular Mode variability. J. Geophys. Res. 113:C03S90. doi: 10.1029/2007jc004269

Staniland, I. J., Morton, A., Robinson, S. L., Malone, D., and Forcada, J. (2011). Foraging behaviour in two Antarctic fur seal colonies with differing population recoveries. Mar. Ecol. Progr. Ser. 434, 183-196. doi: 10.3354/meps09201

Stowasser, G., Atkinson, A., McGill, R. A. R., Phillips, R. A., Collins, M. A., and Pond, D. W. (2012). Food web dynamics in the Scotia Sea in summer: a stable isotope study. Deep Sea Res. Part II Top. Stud. Oceanogr. 59, 208-221. doi: 10.1016/j.dsr2.2011.08.004

Suprenand, P. M., and Ainsworth, C. H. (2017). Trophodynamic effects of climate change-induced alterations to primary production along the western Antarctic Peninsula. Mar. Ecol. Progr. Ser. 569, 37-54. doi: 10.3354/meps 12100

Tarling, G. A., Stowasser, G., Ward, P., Poulton, A. J., Zhou, M., Venables, H. J., et al. (2012). Seasonal trophic structure of the Scotia Sea pelagic ecosystem considered through biomass spectra and stable isotope analysis. Deep Sea Res. Part II Top. Stud. Oceanogr. 59, 222-236. doi: 10.1016/j.dsr2.2011.07.002

Trathan, P. N., and Hill, S. L. (eds) (2016). The Importance of Krill Predation in the Southern Ocean. Switzerland: Springer International Publishing.

Tulloch, V. J. D., Plagányi, É. E., Brown, C., Richardson, A. J., and Matear, R. (2019). Future recovery of baleen whales is imperiled by climate change. Glob. Change Biol. 25, 1263-1281. doi: 10.1111/gcb.14573

Tulloch, V. J. D., Plagányi, É. E., Matear, R., Brown, C. J., and Richardson, A. J. (2018). Ecosystem modelling to quantify the impact of historical whaling on Southern Hemisphere baleen whales. Fish Fish. 19, 117-137. doi: 10.1111/faf. 12241

Turner, J., Hosking, J. S., Bracegirdle, T. J., Marshall, G. J., and Phillips, T. (2015). Recent changes in Antarctic Sea Ice. Philos. Trans. R. Soc. A Math., Phys. Eng. Sci. 373:20140163. doi: 10.1098/rsta.2014.0163

Ward, P., Atkinson, A., and Tarling, G. (2012). Mesozooplankton community structure and variability in the Scotia Sea: a seasonal comparison. Deep Sea Res. Part II Top. Stud. Oceanogr. 59-60, 78-92. doi: 10.1016/j.dsr2.2011. 07.004

Ward, P., Tarling, G. A., and Thorpe, S. E. (2018). Temporal changes in abundances of large calanoid copepods in the Scotia Sea: comparing the 1930s with contemporary times. Polar Biol. 41, 2297-2310. doi: 10.1007/s00300-018-23692363

Whitehouse, M. J., Meredith, M. P., Rothery, P., Atkinson, A., Ward, P., and Korb, R. E. (2008). Rapid warming of the ocean around South Georgia, Southern Ocean, during the 20th century: forcings, characteristics and implications for lower trophic levels. Deep Sea Res. Part I Oceanogr. Res. Pap. 55, 1218-1228. doi: 10.1016/j.dsr.2008.06.002

Williams, R. (1985). "Trophic relationships between pelagic fish and euphausiids in Antarctic waters," in Antarctic Nutrient Cycles and Food Webs, eds W. R. Siegfried, P. R. Condy, and R. M. Laws, (Berlin: Springer-Verlag), 452-459. doi: 10.1007/978-3-642-82275-9_63

Zasel'sliy, V. S., Kudrin, B. D., Poletayev, V. A., and Chechenin, S. C. (1985). Some features of the biology of Electrona carlsbergi (Taning) (Myctophidae) in the Atlantic sector of the Antarctic. J. Ichthyol. 25, 163-166.

Conflict of Interest Statement: The authors declare that the research was conducted in the absence of any commercial or financial relationships that could be construed as a potential conflict of interest.

Copyright (c) 2019 Saunders, Hill, Tarling and Murphy. This is an open-access article distributed under the terms of the Creative Commons Attribution License (CC BY). The use, distribution or reproduction in other forums is permitted, provided the original author(s) and the copyright owner(s) are credited and that the original publication in this journal is cited, in accordance with accepted academic practice. No use, distribution or reproduction is permitted which does not comply with these terms. 